\title{
Science and Technology of High Performance Ferritic (HiperFer) Stainless Steels
}

\author{
Bernd Kuhn ${ }^{1, *} \mathbb{\infty}$, Michal Talik ${ }^{1,+}$, Torsten Fischer ${ }^{1}{ }^{\mathbb{D}}$, Xiuru Fan ${ }^{1}$, Yukinori Yamamoto ${ }^{2}$ and \\ Jennifer Lopez Barrilao ${ }^{1, \ddagger}$ \\ 1 Institute of Energy and Climate Research (IEK), Microstructure and Properties of Materials (IEK-2), \\ Forschungszentrum Juelich GmbH, 52425 Jülich, Germany; michal.talik@voestalpine.com (M.T.); \\ t.fischer@fz-juelich.de (T.F.); x.fan@fz-juelich.de (X.F.); je.lopez@fz-juelich.de (J.L.B.) \\ 2 Materials Science and Technology Division, Oak Ridge National Laboratory, Oak Ridge, TN 37831-6115, \\ USA; y.yamamoto@ornl.gov \\ * Correspondence: b.kuhn@fz-juelich.de; Tel.: +49-2461-61-4132 \\ † Current address: Voestalpine Böhler Welding UTP Maintenance GmbH, Elsäßer Str. 10, 79189 Bad \\ Krozingen, Germany. \\ $\ddagger$ Jennifer Lopez Barrilao, Independent Researcher, 52425 Jülich, Germany.
}

Received: 6 March 2020; Accepted: 31 March 2020; Published: 2 April 2020

\begin{abstract}
Future, flexible thermal energy conversion systems require new, demand-optimized high-performance materials. The High performance Ferritic (HiperFer) stainless steels, under development at the Institute of Microstructure and Properties of Materials (IEK-2) at Forschungszentrum Jülich $\mathrm{GmbH}$ in Germany, provide a balanced combination of fatigue, creep and corrosion resistance at reasonable price. This paper outlines the scientific background of alloy performance development, which resulted in an age-hardening ferritic, stainless steel grade. Furthermore, technological properties are addressed and the potential concerning application is estimated by benchmarking versus conventional state of the art materials.
\end{abstract}

Keywords: HiperFer; fatigue; creep; reactive strengthening; laves phase

\section{Introduction}

The German "Energiewende" poses demanding challenges with regard to the development, operation and maintenance of flexible, regenerative energy converters and storage systems (e.g., pumped thermal electricity storage [1,2], concentrating solar power [3,4], biomass firing, power-to-X technologies [5], etc.) and conventional back-up power plants. At present, development is focused on process related issues, with development of new materials, suitable to meet future requirements, not playing a major role. The knowledge of cyclic, microstructural damage and its effect on the failure mechanisms and potentially associated loss of lifetime of conventional heat resistant, structural materials is in need of improvement. The development of new materials, optimized for cyclic operation, suffers from this shortcoming.

So-called advanced ferritic-martensitic (AFM) 9-12 wt.\% Cr steels, which feature tempered martensite structure and offer creep strength and corrosion resistance up to application temperatures of 600 to $620^{\circ} \mathrm{C}$ [6,7], are typical, (low-cost) structural materials for ultra-supercritical steam power plants. Because of limited steam oxidation resistance the $9 \mathrm{wt} . \% \mathrm{Cr}$ materials cannot be applied beyond $620{ }^{\circ} \mathrm{C}$ [7]. Improved $12 \mathrm{wt} . \%$ chromium AFM steels were developed, but do exhibit a sigmoidal decrease in creep strength [8], caused by the formation of the so-called Z-phase (a complex $\mathrm{Cr}(\mathrm{V}, \mathrm{Nb}) \mathrm{N}$ compound) at the expense of strengthening MX particles $[9,10]$ during long-term application. However, an increase in chromium content is considered essential to ensure sufficient steam oxidation 
resistance [11,12] up to temperatures of $650^{\circ} \mathrm{C}$. Furthermore, 9-12 $\mathrm{Cr}$ steels are not resistant to downtime corrosion, which is one of the main reasons for a significant increase in expenses for conservation of flexibly operated German power plants [13]. In the light of the quite complex alloy composition of AFM steels and the multitude of new requirements from future power engineering, the further development of this alloy class seems to be left at an irresolvable conflict of aims.

Novel high chromium High performance Ferritic (HiperFer) [14] steels, developed by Forschungszentrum Jülich $\mathrm{GmbH}$, Germany provide a promising way out of this technological dead end. Strengthening of ferritic stainless steel cannot be accomplished by MX particles, because of the lacking $\mathrm{C}$ and $\mathrm{N}$ solubility in the fully ferritic matrix. In contrast, alloying by suitable amounts of niobium and tungsten ensures a combination of solid solution and intermetallic $(\mathrm{Fe}, \mathrm{Cr}, \mathrm{Si})_{2}(\mathrm{Nb}, \mathrm{W})$ Laves particle strengthening, which enables creep strength potential beyond grade 92 [14-16] and steam oxidation resistance superior to $12 \mathrm{wt} . \% \mathrm{Cr}$ AFM steels [16]. Operational flexibility will strongly grow in importance in future thermal power conversion [13]. For this reason, increased thermomechanical fatigue resistance $[14,17,18]$ was the main focus of HiperFer development, with creep strength as a subordinate, but still relevant issue. HiperFer steel is fully ferritic, without martensitic re-transformation in the welding cycle, and for this reason intrinsically free from so-called TypeIV (i.e., fine-grain heat-affected zone) cracking.

\section{Materials and Methods}

\subsection{Alloy Design}

Having low solubility $[19,20]$ and comparably high diffusion rate $[21,22]$ in ferrite, $\mathrm{Nb}$ is a key element in the design of ferritic, stainless, intermetallic particle strengthened steel. It is a strong Laves-phase former [23] and in combined alloying with tungsten, for improved solid solution strengthening, and silicon to accelerate nucleation [24-28], forms a thermodynamically stable $(\mathrm{Fe}, \mathrm{Cr}, \mathrm{Si})_{2}(\mathrm{Nb}, \mathrm{W})$-Laves phase $[16,29,30]$. With $\mathrm{Nb}$ being a strong carbonitride former it is necessary to restrict $\mathrm{C}$ and $\mathrm{N}$ to a minimum $(<0.01 \mathrm{wt} . \%)$, because even small contents of these species may decrease the amount of $\mathrm{Nb}$ available [28,31-33] for Laves phase precipitation. Furthermore, primary TiN particles may act as nucleation sites of niobium consuming $\mathrm{Nb}(\mathrm{C}, \mathrm{N})[34,35]$, which may additionally affect the formation and stability of the desired Laves phase particles in a negative way. The implications for the design of Laves phase strengthened, ferritic, stainless steels for structural applications are covered in detail in $[16,36]$.

The aims of alloy development are manifold: First, maximization of the amount of strengthening Laves phase was desired to increase fatigue and creep strength. Second, the content of the $(\mathrm{Fe}, \mathrm{Cr})-\sigma-p h a s e$, which usually is considered to deteriorate ductility, hot-workability and weldability, corrosion resistance and long-term thermomechanical fatigue properties [37-40], should be restricted to a minimum (favorably below $600{ }^{\circ} \mathrm{C}$ ). Third, just one single strengthening intermetallic phase-the Laves phase-was sought (i.e., precipitation of e.g., $\chi\left(\mathrm{Fe}_{36} \mathrm{Cr}_{12} \mathrm{~W}_{10}\right)$ and $\mu\left(\mathrm{Fe}_{7} \mathrm{~W}_{6}\right)$ phase should be avoided) in the envisaged operation temperature range from 580 to $650{ }^{\circ} \mathrm{C}$ to facilitate welding and long-term stability of microstructure. Spinodal decomposition, i.e., nucleation of a second, Cr-rich ferrite phase (cf. Figure 1: $\alpha-\mathrm{Cr}$ ) at low temperature, should be minimized and improvement of mechanical properties should not be accomplished on the expense of corrosion and steam oxidation resistance in comparison to the $22 \mathrm{Cr}$ model steels covered in [16].

Changes in chemical composition do not only directly affect application properties, but also the temperature window and characteristics of processing (cf. Figure 1). Materials suitable for common processing (of e.g., tubes, pipes, plates, sheets, forgings, etc.) temperatures of stainless steels $\left(950-1200^{\circ} \mathrm{C}\right.$ ) are favored. Regarding this multitude of prerequisites, thermodynamic equilibrium calculations were carried out, utilizing the software package Thermo-Calc ${ }^{\circledR}$ (applying database version TCFE7) for the nominal compositions of both the trial alloy types. 


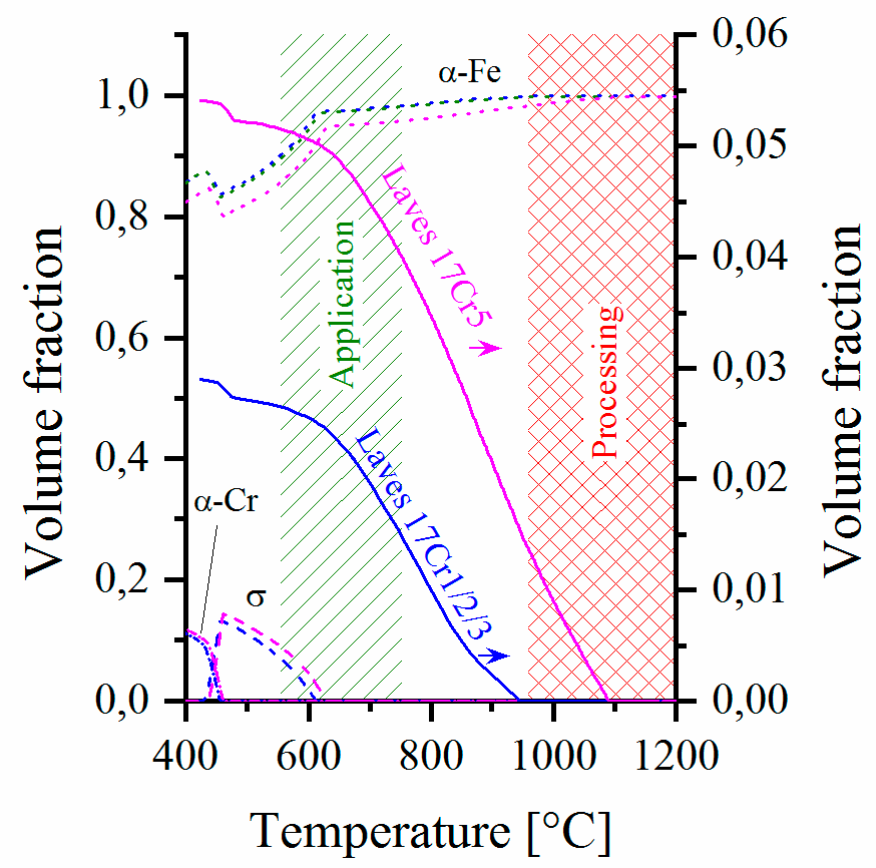

Figure 1. Simplified phase diagrams of the $17 \mathrm{Cr} 1 / 2$ "workhorse" (nominal: $17 \mathrm{Cr}, 2.6 \mathrm{~W}, 0.6 \mathrm{Nb}, 0.25 \mathrm{Si}$ ) and the advanced $17 \mathrm{Cr} 5$ (nominal: $17 \mathrm{Cr}, 4 \mathrm{~W}, 1 \mathrm{Nb}, 0.25 \mathrm{Si}$ ) trial steels (Thermo-Calc ${ }^{\circledR}$, TCFE7).

According to these the lower alloyed "workhorse" $17 \mathrm{Cr} 1 / 2$ steel (nominal: $17 \mathrm{Cr}, 2.6 \mathrm{~W}, 0.6 \mathrm{Nb}$, $0.25 \mathrm{Si}$ ) contains a volume fraction of about $2.23 \mathrm{vol} . \%$ of Laves phase at $650{ }^{\circ} \mathrm{C}$. The increased $\mathrm{W}$ - and $\mathrm{Nb}$-contents of the advanced $17 \mathrm{Cr} 5$ (nominal: $17 \mathrm{Cr}, 4 \mathrm{~W}, 1 \mathrm{Nb}, 0.25 \mathrm{Si}$ ) composition yield a more than doubled volume fraction of $4.82 \mathrm{vol} . \%$. According to the calculation, both steels contain small contents of the $\sigma$ - and $\alpha$-Cr-phases below 610 and $450{ }^{\circ} \mathrm{C}$, respectively.

While it is known that thermodynamic calculation overestimates the $\sigma$-phase range in this alloying system [16], no practical information on the calculation accuracy is available concerning the $\alpha$-Cr-phase, as far as the authors are aware of. The calculated chromium concentration of the ferrite matrix does not drop below $16.5 \mathrm{wt} . \%$ in the application temperature range and thus ensures sufficient steam oxidation [11] and downtime corrosion [41,42] resistance.

The two trial alloy types are characterized by a fundamental difference: The low-alloyed 17Cr1/2 workhorse composition represents an alloy, similar to (but not matching) the philosophy of current AFM steels, which need multi-step quality heat treatment to reach optimum strength. In the case of AFM steel, this consists of austenitizing with martensitic transformation during subsequent rapid cooling and a second (or even third) holding step at temperatures (comparatively far) above the envisaged application temperature for stress relief and precipitation heat treatment. With kinetics being tuned to rapid precipitation HiperFer $17 \mathrm{Cr} 1 / 2$ can either be put into service in the cold-rolled or recrystallized + precipitation heat treated state, or precipitation heat treatment could potentially be executed during plant commissioning (outlined in Section 2.4). Standard quality heat treatment above application temperature thus becomes obsolete. This batch served as the "workhorse" to study the fundamental interactions of chemistry, processing, precipitation, resulting microstructure and mechanical properties. The gained know-how then was transferred to the advanced $17 \mathrm{Cr} 5$ variant, which is designed for age-hardening and thus redundantizes any standard quality and even simplified precipitation heat treatment (additional to recrystallization for grain size adjustment) after the forming process. The increase in tungsten content reduces primary creep strain by increased solution strengthening, while the higher content of niobium boosts precipitation kinetics and thus minimizes accumulation of creep strain during decomposition of the supersaturated solid solution and nucleation of the strengthening Laves phase precipitates in the early primary creep stage. 


\subsection{Base Material Production, Processing and Picrostructure}

The model steels were produced by the Steel Institute (IEHK) of the Northrhine-Westfalian Technical University Aachen (RWTH), Germany from high purity raw materials by vacuum induction melting of $80 \mathrm{~kg}$ ingots and casting to original block dimensions of $140 \mathrm{~mm} \times 140 \mathrm{~mm} \times 525 \mathrm{~mm}$. The blocks were then forged to $80 \mathrm{~mm} \times 56 \mathrm{~mm}$, air cooled and cut into pieces of $135 \mathrm{~mm}$ in length. Subsequently soaking was carried out at $1140-1180{ }^{\circ} \mathrm{C}$ for $2 \mathrm{~h}$. The $17 \mathrm{Cr} 1$ blocks were hot-rolled to a final plate thickness of $15.5 \mathrm{~mm}$ at $1000^{\circ} \mathrm{C}$ and subsequently air-cooled, while the $17 \mathrm{Cr} 2$ material was cold-rolled $920^{\circ} \mathrm{C}$ and subsequently water quenched.

Hot-rolling (referred to as "HR" in the following text) above the dissolution temperature of the Laves phase in combination with comparably slow air cooling leads to almost globular grain morphology with low dislocation density and few, small Laves phase particles, mainly located at high angle grain boundaries (Figure 2a). In contrast, cold-rolling ("CR" in the following) below the dissolution temperature of the Laves phase, followed by rapid water quenching, results in a typical deformation morphology with elongated grains (Figure 2b), high dislocation density and rarely any Laves phase particles. Globular grain morphology can be obtained by recrystallization annealing above the Laves phase dissolution temperature. To obtain equi-axed, globular grain structure and full dissolution of Laves phase particles (originating from preceding forming), the rolled 17Cr2 plates were annealed at $1025-1050{ }^{\circ} \mathrm{C}$ for $15 \mathrm{~min}$ and subsequently water quenched. $1100-1125^{\circ} \mathrm{C}$ for 25 min were applied in case of the $17 \mathrm{Cr} 5$ plates.

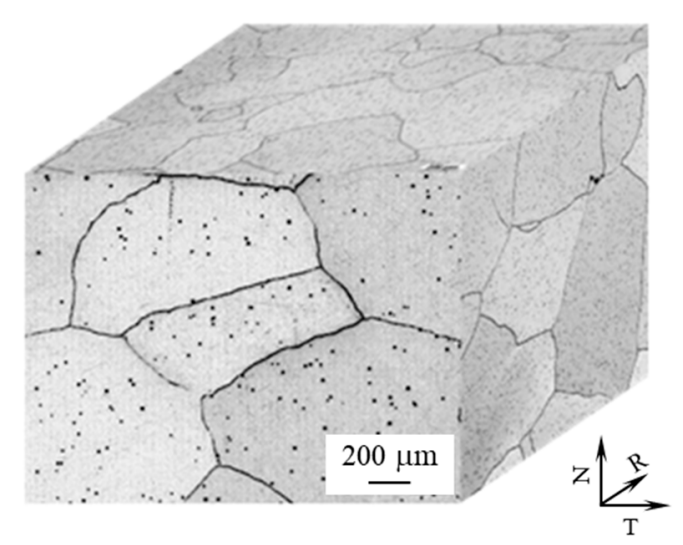

(a)

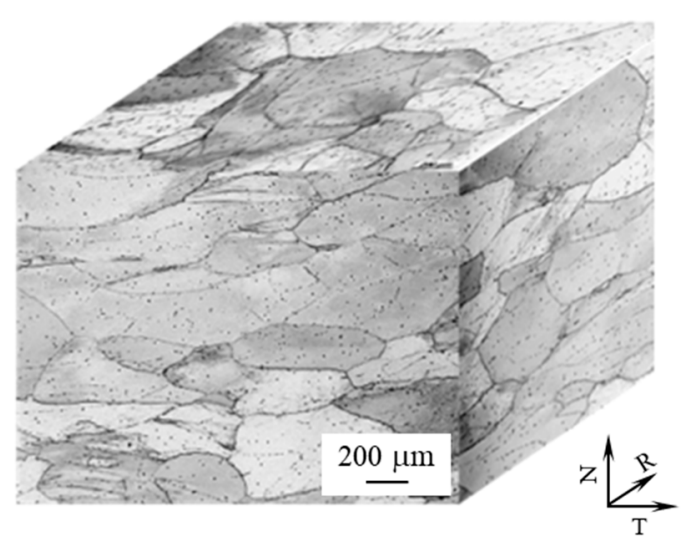

(b)

Figure 2. Typical microstructures of (a) hot-rolled 17Cr1 and (b) cold-rolled 17Cr2 HiperFer steel (R: Rolling, T: Transversal, N: Normal direction of rolled plate material; obtained from optical micrographs taken from the three directions).

The chemical compositions of the trial steels (analyzed by Inductively Coupled Plasma Optical Emission Spectroscopy (ICP-OES); C, N analyzed by infrared absorption) and commercial 316L, grade 92, MarBN (from original material certificates) are given in Table 1.

Commercial grade $92\left(1040-1070{ }^{\circ} \mathrm{C}, 2 \mathrm{~h} / 730-800{ }^{\circ} \mathrm{C}, 2 \mathrm{~h}\right)$ material was supplied in the form of billet (diameter: $200 \mathrm{~mm}), \operatorname{MarBN}\left(1120{ }^{\circ} \mathrm{C} / 1 \mathrm{~h} /\right.$ air cooling $+700{ }^{\circ} \mathrm{C} / 2 \mathrm{~h} /$ air cooling $+700{ }^{\circ} \mathrm{C} / 4$ $\mathrm{h}$ /air cooling) in slab form of $100 \mathrm{~mm} \times 200 \mathrm{~mm} \times 68 \mathrm{~mm}$ dimension and 316L as sheet product of 16 mm thickness. 
Table 1. Chemical composition (wt.-\%) of the ferritic trial alloys and benchmark steels.

\begin{tabular}{ccccccccccccc}
\hline Batch-ID: & $\mathbf{C}$ & $\mathbf{N}$ & $\mathbf{C r}$ & $\mathbf{M n}$ & $\mathbf{S i}$ & $\mathbf{N b}$ & $\mathbf{W}$ & $\mathbf{V}$ & A1 & Ni & Mo & B \\
\hline HiperFer 17Cr1 & $<0.01$ & $<0.01$ & 16.7 & 0.46 & 0.23 & 0.56 & 2.42 & - & - & - & - & - \\
\hline HiperFer 17Cr2 & $<0.01$ & $<0.01$ & 17.1 & 0.18 & 0.25 & 0.63 & 2.41 & - & - & - & - & - \\
\hline HiperFer 17Cr5 & $<0.01$ & $<0.01$ & 17.2 & 0.20 & 0.27 & 0.99 & 3.70 & - & - & - & - & - \\
\hline 316L & 0.024 & 0,07 & 16.85 & 1.35 & 0.44 & - & - & - & - & 10.00 & 2.06 & - \\
\hline Grade 92 & 0.16 & 0.051 & 8.96 & 0.46 & 0.04 & 0.069 & 1.84 & 0.2 & 0.007 & 0.06 & 0.47 & 0.001 \\
\hline & & & & & & Nd & & & & & Co & \\
\hline MarBN & 0.09 & 0.009 & 8.97 & 0.48 & 0.25 & 0.03 & 3.0 & 0.2 & 0.01 & 0.09 & 3.0 & 0.011 \\
\hline
\end{tabular}

\subsection{Trial Welds}

First trial welds of as-rolled plate material (machined to $12 \mathrm{~mm}$ in thickness) were produced by gas tungsten arc welding (GTAW) at the Oak Ridge National Laboratory Materials Science and Technology Division, applying compositionally matching metal strips (1.6 mm diameter), taken from the base metal plates. A single V-shape groove was filled with compositionally matched weld filler metal by eleven weld beads, which were applied in a pre-heat and inter-pass temperature range from 120 to $150{ }^{\circ} \mathrm{C}$. Visual inspection of the weld surface and cross-sectional observation did not reflect welding related defects and the welds successfully passed the ASTM E190-14 [43] side bend test. These welds intentionally represent the worst-case scenario of a high dislocation density (i.e., as-rolled, forged, bent) material, being welded and later on put into service without conventional post-weld heat treatment. Microstructural changes, i.e., recovery of excess dislocations or partly recrystallization and consequently a drop in dislocation strengthening within the heat-affected zone, are inevitable under these prerequisites. Details on weld microstructure can be found in [44].

\subsection{Heat Treatment}

HiperFer is designed to stay fully ferritic at all temperatures to keep it free from fine grain formation in the heat-affected zones of welds [45,46]. For this reason the mechanical properties of this type of steel are highly dependable on processing (i.e., rolling, forging, bending, welding), because it does not undergo martensitic transformation even during rapid cooling, which is implemented to prevent uncontrolled formation of precipitates, from process heat. This results in comparatively low dislocation density (i.e., less nucleation sites for strengthening precipitates) and thus comparably low, expected mechanical strength in the as-processed state. This could be counterbalanced by tailored thermomechanical processing [44] like cold-rolling. Mechanical properties depending on thermomechanical processing might restrict utilization of the proposed steels to applications, where component production and plant construction do not cause significant microstructural alterations, e.g., to components, which are not welded. Furthermore, implied complexity and additional cost might prohibit market entry or deeper market penetration.

This drawback is resolved by tailored precipitation kinetics, which enable simplified, short-term precipitation annealing (PA) in the envisaged application temperature range. Potentially, even precipitation heat treatment during plant commissioning would be feasible. Annealing for 0.5 to $10 \mathrm{~h}$ in the temperature range from 600 to $650{ }^{\circ} \mathrm{C}$, followed by water quenching is effective in increasing the mechanical properties of hot-rolled and restoring the properties of recrystallization annealed HiperFer material. A typical resulting microstructure is depicted in Section 3.1 (cf. Figure 4). Intra- and intergranular precipitation of small Laves phase particles effectively strengthens the material. High angle grain boundaries are characterized by alongside particle-free zone (PFZ) formation, which can be influenced by alloy composition and heat-treatment. Engineering these PFZs is important in controlling creep ductility (cf. [47] and Section 3.4.2, Figure 11). 


\subsection{Mechanical Testing}

For tensile, creep and relaxation testing cylindrical specimens with gauge diameters of $6.4 \mathrm{~mm}$ and gauge lengths of $30 \mathrm{~mm}$ were applied. All samples for mechanical testing were taken from the plate materials perpendicular to the rolling direction.

The tensile experiments were performed at strain rates of $10^{-3} \mathrm{~s}^{-1}$ at ambient (according to DIN EN 10002-1) and 8.33·10 ${ }^{-5} \mathrm{~s}^{-1} / 8.33 \cdot 10^{-4} \mathrm{~s}^{-1}$ (in the elastic/plastic range, according to DIN EN 10002-5) at elevated temperatures, utilizing an Instron (Norwood, MA, USA) Type 1362 testing machine with $10 \mathrm{kN}$ of load capability.

Creep experiments were carried out in single specimen, constant load, lever-arm type creep machines, with continuous elongation measurement at the gauge portions of the specimens. In case of specimens tested at stress levels below $100 \mathrm{MPa}$ only the primary creep stages were recorded in single specimen machines. Upon entering the secondary stage of creep the samples were transferred to multi-specimen machines for long-term testing (unless otherwise stated) in discontinuous creep experiments with periodical measurement of specimen strain. Optical strain measurements were carried out after cooling to ambient temperature, unloading and taking the specimens from the testing equipment for length measurement. This procedure was repeated in nominally $1000 \mathrm{~h}$ intervals until rupture. Electrical three-zone furnaces, controlled to the specified testing temperatures with an accuracy of $+/-2{ }^{\circ} \mathrm{C}$, were used in the tensile and single specimen creep experiments. The multi-specimen machines for discontinuous creep testing were equipped with electrical five-zone furnaces, controlled to an accuracy of $+/-3^{\circ} \mathrm{C}$.

Relaxation experiments were executed utilizing an Instron Type 1362 testing machine with $10 \mathrm{kN}$ of load capability. At testing temperature, the specimens were loaded to the initial stress level (250 MPa @ 600 and $200 \mathrm{MPa} @ 650{ }^{\circ} \mathrm{C}$ ), applying a controlled strain rate of $10^{-3} \mathrm{~s}^{-1}$. The relaxation then was initiated by switching the machine to strain control. While the strain level reached after loading was kept constant stress relaxation was recorded.

Type $\mathrm{R}(\mathrm{Pt} / \mathrm{RhPt})$ thermocouples were attached to the specimen gauge lengths for temperature control in tensile tests and continuous creep testing, while shielded (Type R) temperature measuring rods, in close vicinity to the specimens, were utilized in interrupted creep testing. In tensile, creep and relaxation testing all specimens were heated to the designated testing temperature at a rate of $5 \mathrm{~K} / \mathrm{min}$. and maintained for about one hour before starting the testing machine or applying the load for ensuring thermal equilibrium conditions.

According to the European Code-of-Practice [48] strain controlled thermomechanical fatigue (TMF) testing was executed at cylindrical specimens with a gauge length of $15 \mathrm{~mm}$ and a diameter of $7 \mathrm{~mm}$, utilizing servo-hydraulic fatigue testing systems with inductive specimen heating. Type $\mathrm{R}$ sling thermocouples were utilized to control temperature. A so called "out-of-phase cycle (oop)" was started by heating from the minimum temperature of $50{ }^{\circ} \mathrm{C}$ to $650^{\circ} \mathrm{C}$ maximum temperature at a controlled rate of $10 \mathrm{Ks}^{-1}$. After reaching the maximum temperature the specimen was immediately cooled down at the same rate $\left(10 \mathrm{Ks}^{-1}\right)$ by compressed air, i.e., no holding times were implemented into the cycle, to restrict creep to a minimum. During heating and cooling the thermal expansion of the material was either fully (100\% oop) or partly $\left(80,60,45 \%\right.$ oop) obstructed by the testing machine. Below $\sim 150{ }^{\circ} \mathrm{C}$, cooling was retarded due to insufficient amounts of cooling air. For this reason, the duration of the cooling cycle was $85 \mathrm{~s}$. The duration of the whole cycle was $145 \mathrm{~s}$.

Fatigue crack growth (FCG) experiments at compact tension (CT) specimens were accomplished utilizing a servo-hydraulic Instron (Norwood, Massachusetts, USA) Model 1343 testing machine with inductive heating. A modified specimen geometry (width, W: $40 \mathrm{~mm}$, thickness, B: $10 \mathrm{~mm}$, machined notch depth, $a_{n}: 10 \mathrm{~mm}$ ) was utilized, because of limited material availability. The dimensions are in accordance with the ASTM fatigue crack growth testing standard [49]. Pre-cracking of the specimens up to a starter crack length $\mathrm{a}_{0}$ to width ratio $(\mathrm{a} / \mathrm{W})$ of 0.4 was performed at ambient temperature in an Instron Model 1603 resonance tester. The direct current potential drop (PD) technique was employed to record crack length during the FCG experiments. Sinusoidal waveform at constant load ratio $(R=0.1)$ 
was applied until the termination criterion of $\mathrm{a} / \mathrm{W}=0.7$ was reached. The cyclic stress intensity factor $(\Delta \mathrm{K})$ was determined following the method specified in ASTM E647 [49]. The cyclic crack growth rate was evaluated by the 7-point polynomial method proposed by ASTM E647 [49].

A Zwick Roell (Ulm, Germany) $50 \mathrm{~J}$ miniature hammer was utilized in impact testing of $27 \mathrm{~mm}$ $\times 3 \mathrm{~mm} \times 4 \mathrm{~mm}$ KLST specimens $\left(60^{\circ}\right.$ notch angle, $1 \mathrm{~mm}$ depth, notch radius $\mathrm{R}=0.1 \mathrm{~mm}$, distance between anvils: $22 \mathrm{~mm}$ ), because of limited material availability. A conversion function was established by comparison of DIN V and KLST impact energy results of solution-annealed material, following the procedure outlined by Schill et al. [50].

\subsection{Microstructural Investigation}

Specimens for the investigation of initial microstructure were electrically discharge machined (EDM) from the plate materials. For metallographic characterization the specimens were mounted in epoxy resin, ground and polished to a sub-micron finish in colloidal silica suspension and $\mathrm{Al}_{2} \mathrm{O}_{3}$ in dilute $\mathrm{KOH}$ solution for approx. $4 \mathrm{~h}$ and subsequently electrolytically etched at $1.5 \mathrm{~V}$ in $5 \% \mathrm{H}_{2} \mathrm{SO}_{4}$ to enhance the particle/matrix contrast and to increase discriminability of the smallest $(<30 \mathrm{~nm})$, very closely located particles. Characterization was accomplished by light optical (Leica MEF4, Wetzlar, Germany) and scanning electron microscopy with energy and/or wavelength dispersive X-ray spectroscopy (Zeiss Merlin, Oberkochen, Germany) / Oxford Instruments Inca/Wave (Abingdon, UK)).

\section{Results and Discussion}

\subsection{Tensile Strength}

The tensile strength of hot-rolled $17 \mathrm{Cr} 1$ plate material is comparatively low (cf. 17Cr1 HR in Figure 3a), when directly compared to ferritic-martensitic steel [51]. Rolling at lower temperature (i.e., below the dissolution temperature of the Laves phase) leads to a moderate rise in tensile strength in case of the cold-rolled $17 \mathrm{Cr} 2$ batch (cf. $17 \mathrm{Cr} 2 \mathrm{CR}$ in Figure 3a).

By heat treatment (cf. 17Cr2 RX + PA in Figure 3a), almost doubled ambient temperature tensile strength values are obtainable in case of the workhorse alloy. In the advanced $17 \mathrm{Cr} 5$ trial steel the increased $\mathrm{W}$ and $\mathrm{Nb}$-contents cause increased tensile strength by improved solid solution hardening already in the recrystallized state (cf. Figure 3b: RX). After precipitation annealing the yield and tensile strength values, as well as rupture elongation ( 15\% at ambient, $>25 \%$ at high temperature), approach the range of AFM steels (cf. Figure 3b: RX + PA, exemplary microstructure in Figure 4) [52].

As a summary it can be stated, that simple precipitation annealing mainly yields strongly increased ultimate tensile and moderately improved yield strength values. If further enhanced yield strength is desired, increased dislocation density (e.g., induced by thermomechanical processing) is a measure of choice. There are obviously several effective ways to adjust the short-term mechanical properties within this alloying system. The optimum way apparently depends on the designated application, which dictates the details of material specification. 


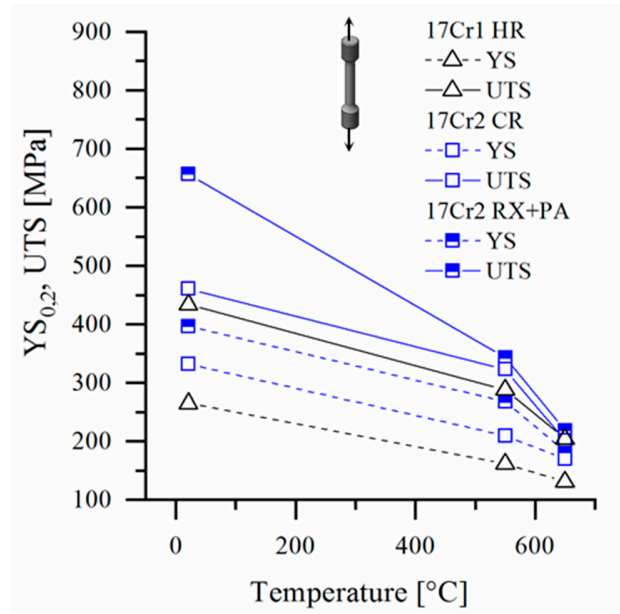

\begin{tabular}{crcc}
\hline \multicolumn{4}{c}{ Rupture elongation [\%] } \\
T [ ${ }^{\circ} \mathbf{C}$ ] & AT & $\mathbf{5 5 0}$ & 650 \\
\hline $17 \mathrm{Cr} 1 \mathrm{HR}$ & 26.1 & 24.6 & 29.1 \\
\hline $17 \mathrm{Cr} 2 \mathrm{CR}$ & 22.9 & 23.4 & 24.8 \\
\hline $17 \mathrm{Cr} 2 \mathrm{RX}+\mathrm{PA}$ & 19.7 & 20.3 & 23.4 \\
\hline
\end{tabular}

(a)

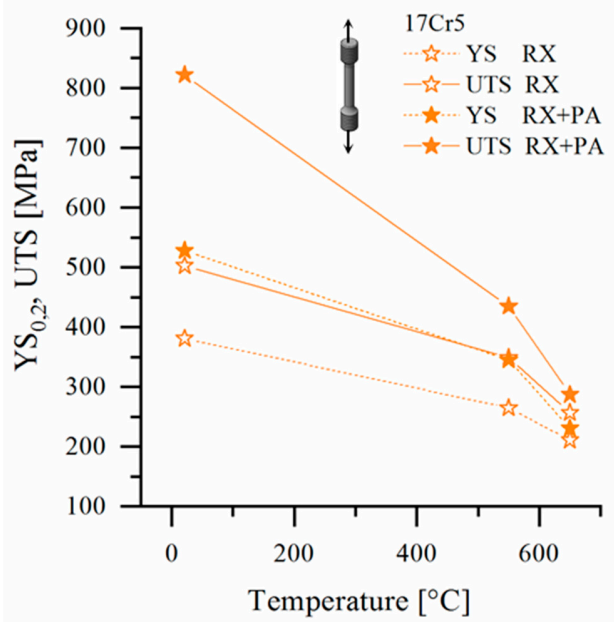

\begin{tabular}{cccc}
\hline \multicolumn{4}{c}{ Rupture elongation [\%] } \\
T [ $\left.{ }^{\circ} \mathbf{C}\right]$ & AT & $\mathbf{5 5 0}$ & 650 \\
\hline $17 \mathrm{Cr} 5 \mathrm{RX}$ & 25.6 & 17.6 & 22.7 \\
\hline $17 \mathrm{Cr} 5 \mathrm{RX}+\mathrm{PA}$ & 14.1 & 14.8 & 19.1 \\
\hline
\end{tabular}

(b)

Figure 3. Tensile strength values of (a) the hot-rolled (HR) 17Cr1, the cold-rolled (CR), recrystallized and precipitation annealed $(\mathrm{RX}+\mathrm{PA}) 17 \mathrm{Cr} 2$ and $(\mathbf{b})$ the recrystallized $(\mathrm{RX})$ and recrystallization and precipitation annealed ( $\mathrm{RX}+\mathrm{PA}) 17 \mathrm{Cr} 5$ trial steels (AT: ambient temperature).

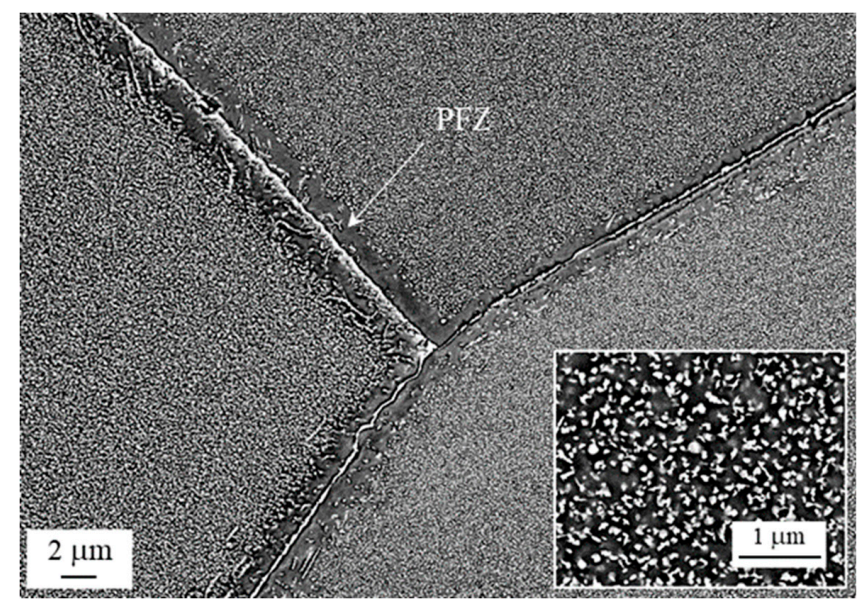

Figure 4. Exemplary microstructure of the recrystallized and precipitation annealed $17 \mathrm{Cr} 5(\mathrm{RX}+\mathrm{PA})$ steel taken from a specimen head section after tensile testing (cumulated time from 600 to $650{ }^{\circ} \mathrm{C}$ : $2.75 \mathrm{~h}$ ): Small, evenly distributed, intragranular Laves phase precipitates, almost fully covered grain boundaries with alongside formation of characteristic particle free zones (PFZ). 


\subsection{Short Crack Initiation and Growth: Technical Lifetime in Thermomechanical Fatigue Loading}

The potential performance of material classes in future, flexible operation has not been considered in an adequate way by the experts yet. Thermomechanical fatigue testing can be considered as most relevant to practice, when concerning the technical lifetime of thick section components as the most critical elements in cyclic plant operation. Figure 5a displays typical thermomechanical fatigue life curves from $100 \%$ oop thermomechanical fatigue experiments. The thermal expansion of the specimens is fully obstructed in a 100 oop cycle by the testing machine, while cycling between 50 and $650{ }^{\circ} \mathrm{C}$, causing $0.79 \%$ of mechanical strain in case of grade $92,0.76 \%$ in case of HiperFer $17 \mathrm{Cr} 2,1.14 \%$ in case of $316 \mathrm{~L}, 0.75 \%$ in case of MarBN and $0.73 \%$ in case of HiperFer $17 \mathrm{Cr} 5$ steel. Ferritic-martensitic steels (Figure 5a: grade 92, MarBN) exhibit high initial stress range, due to initially high intrinsic dislocation density. During an "initial phase" (approx. 300 cycles in case of grade 92, 700 cycles in case of MarBN), however, the recorded stress range drops by typically one third and the material enters a quasi-"stable" phase of slightly negative slope, which is accompanied by polygonization of the martensite lath structure [18].

Finally, the materials reach the "damage phase", which in AFM steel is characterized by a comparatively steep drop in stress range until final failure. Austenitic steel behaves the opposite way: Because of higher thermal expansion and strength at elevated temperature, it hardens in the initial phase, reaches higher stable stress range, but fails rapidly after damage initiation. Ferritic HiperFer behaves like austenitic steel in terms of cyclic hardening, but the microstructural mechanisms do differ: While in austenite initial strengthening is an effect of cyclic strain hardening, it is intensified by permanent "thermomechanically triggered precipitation" strengthening by Laves phase particles in HiperFer, which is boosted by increased dislocation density. (Cyclic) Plastic deformation not only accelerates precipitation, but furthermore refines particles (cf. Figure 6, in comparison to Figure 4).

Based on this mechanism it reaches stress ranges higher than AFM steel (17Cr2 > grade 92, 17Cr5 $>$ MarBN), approximately on the 316L level (17Cr5) and exhibits comparatively forgiving damage and failure behavior (Figure 5a). Taking into account the outlined differences of the materials, the technical lifetime was determined from the intersection of linear approximations to the "stable" and the "damage" curve sections of the fatigue curves (cf. "N $\mathrm{N}_{\mathrm{f}}$ ", grade 92 curve in Figure 5a). The onset of damage was assessed by deviation of the fatigue curve from a linear approximation to the stable curve section (cf. " $\mathrm{N}_{\mathrm{d}}$ ", grade 92 curve in Figure 5a). Relating technical lifetime $\mathrm{N}_{\mathrm{f}}$ and damage initiation $\mathrm{N}_{\mathrm{d}}$ (Table 2) to each other, demonstrates the more forgiving failure character of the HiperFer alloys, particularly of the 17Cr5 variant, concerning propagation of short cracks.

Thermo-mechanical fatigue life behavior in out-of-phase cycles of varying thermal strain obstruction (from complete, i.e., $\varepsilon_{\text {mech. }}=100 \%$ to $45 \%$ of $\varepsilon_{\text {th. }}$ ) of the HiperFer trial alloys, ferritic-martensitic grades 92 and MarBN as well as austenitic 316L steel is depicted in Figure 5b. In comparison to grade 92, HiperFer $17 \mathrm{Cr} 2$ reaches almost doubled TMF lifetime over the entire span of stress (i.e., strain) ranges. With the lifetime of the recrystallized + precipitation annealed material falling close to the same main line the initial heat treatment state does not play a significant role. MarBN-type steel achieves about twice the number of loading cycles compared to the HiperFer workhorse grade $(17 \mathrm{Cr} 2)$. In the high-alloy version $17 \mathrm{Cr} 5$ precipitate volume fraction and thus strength and reactive hardening has been maximized. In comparison to grade 92 up to 5.5 (to MarBN 2.5 times) longer technical fatigue life is obtainable over the entire stress range, while at high stress ranges it even matches the performance of austenitic 316L (cf. Figure 5a). 


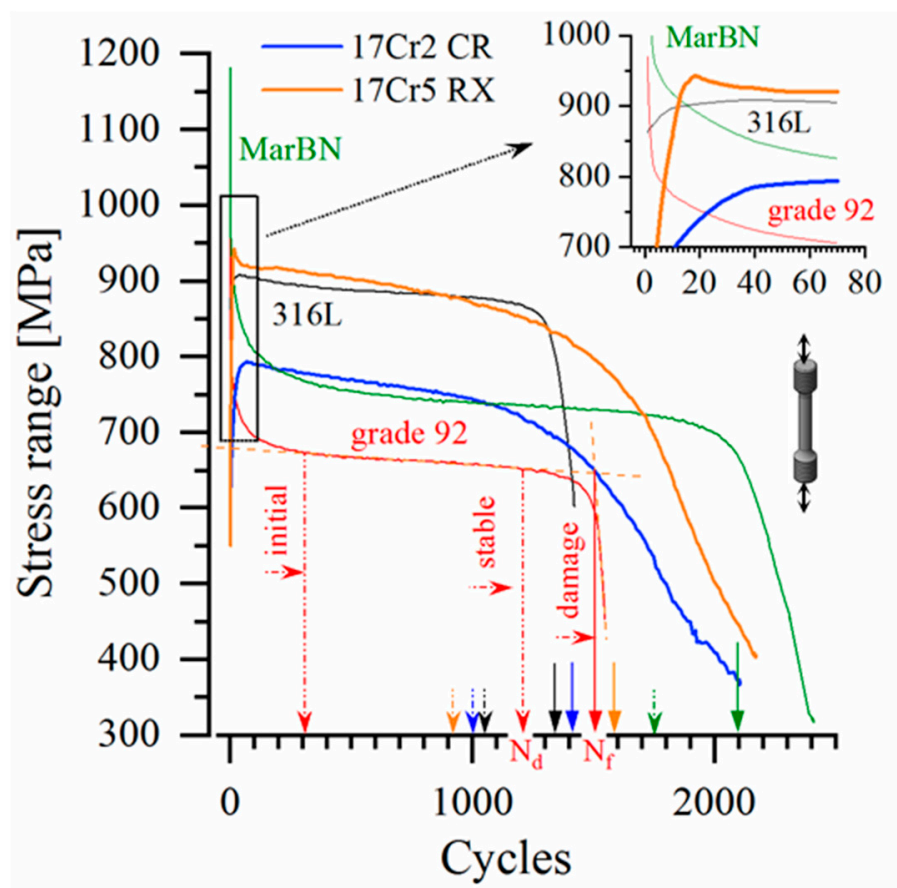

(a)

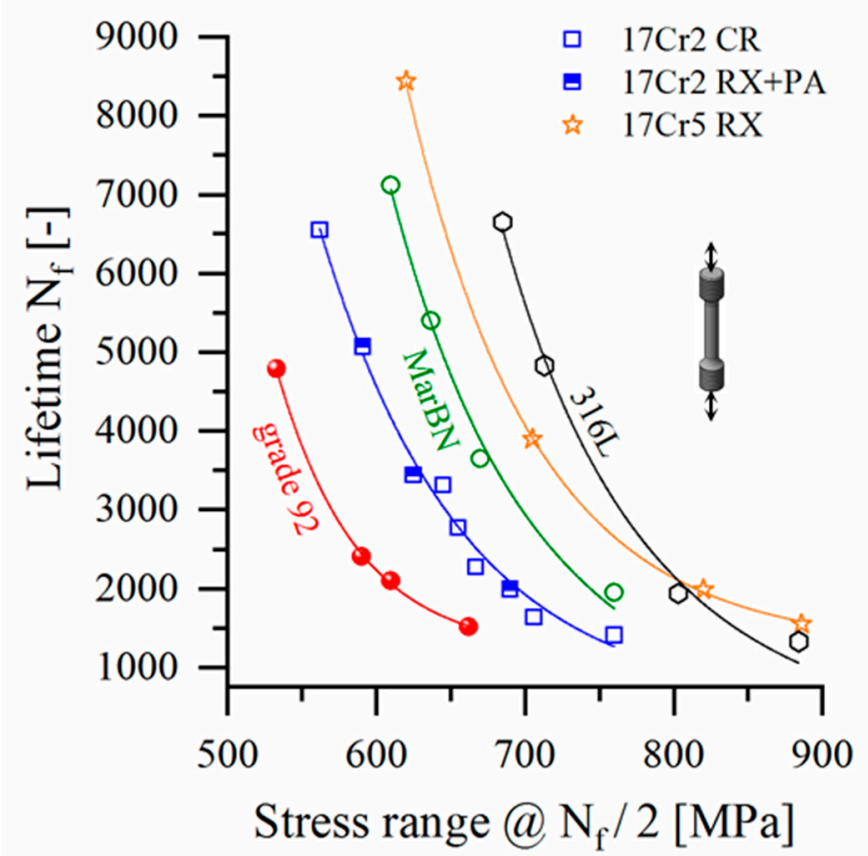

(b)

Figure 5. Thermo-mechanical fatigue testing results of ferritic trial, commercial ferritic-martensitic and austenitic steels $\left(50-650{ }^{\circ} \mathrm{C}, \varepsilon_{\text {mech. }}=-0.45\right.$ to $-1 \varepsilon_{\text {th. }}, 10 \mathrm{Ks}^{-1}$, no holding times at $\mathrm{T}_{\min }$ and $\mathrm{T}_{\max }$ ). (a) Typical fatigue life curves in $100 \%$ out-of-phase cycles $\left(\varepsilon_{\text {mech. }}=-\varepsilon_{\text {th. }}\right)$ and (b) technical lifetime over half-life stress range (i.e., as a result to differing obstruction of thermal strain, $\varepsilon_{\text {mech. }}=-0.45 \varepsilon_{\text {th }}$. to $-\varepsilon_{\text {th. }}$ ). 


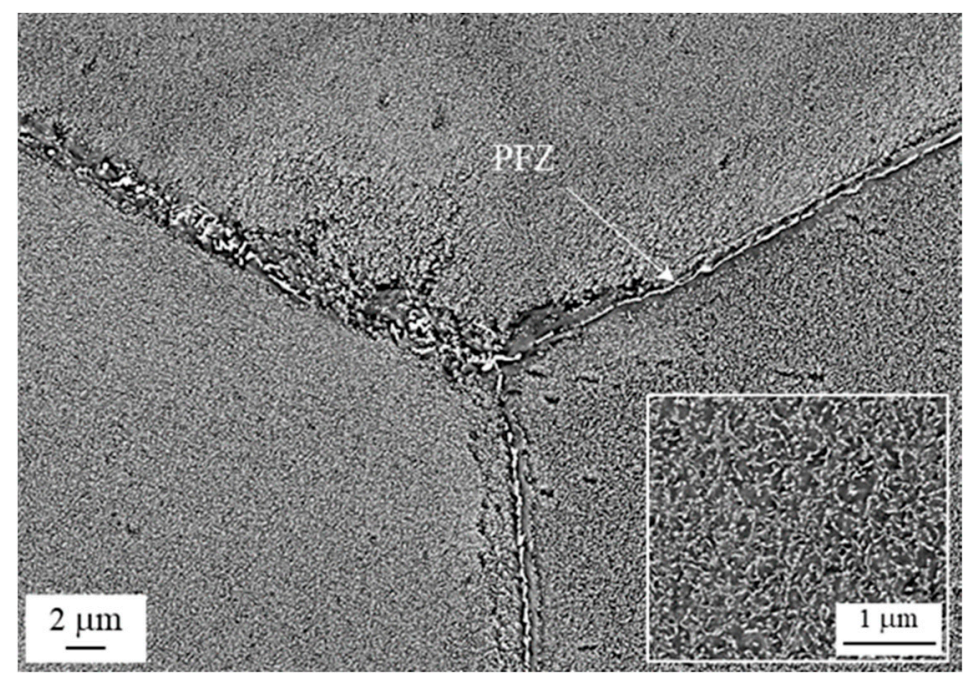

Figure 6. Exemplary microstructure from a $17 \mathrm{Cr} 5 \mathrm{TMF}$ (parameters cf. Figure 5 a specimen (experiment initiated from RX state, interrupted after 1000 cycles, i.e., cumulated time from 600 to $650{ }^{\circ} \mathrm{C}: 2.5 \mathrm{~h}$ ): Refined intragranular Laves phase precipitates, reduced particle free zone (PFZ) width (cf. Figure 4).

Table 2. Half-life stress range, technical TMF lifetime $\mathrm{N}_{\mathrm{f}}$, damage initiation $\mathrm{N}_{\mathrm{d}}$ and damage ranges $\left(50-650{ }^{\circ} \mathrm{C}, \varepsilon_{\text {mech. }}=-\varepsilon_{\text {th }}, 10 \mathrm{Ks}^{-1}\right.$, no holding times at $\mathrm{T}_{\text {min. }}$ and $\left.\mathrm{T}_{\text {max. }}\right)$.

\begin{tabular}{ccccc}
\hline Material: & $\boldsymbol{\sigma} @ \mathbf{N}_{\mathbf{f} / \mathbf{2}}$ & $\mathbf{N}_{\mathbf{d}}$ & $\mathbf{N}_{\mathbf{f}}$ & Damage Range \\
\hline HiperFer 17Cr2 CR & 760 & 974 & 1389 & $29.9 \%$ \\
\hline HiperFer 17Cr5 RX & 886 & 1031 & 1569 & $34.2 \%$ \\
\hline Grade 92 & 662 & 1247 & 1502 & $17.0 \%$ \\
\hline MarBN & 760 & 1768 & 2080 & $15.0 \%$ \\
\hline 316L & 884 & 1143 & 1326 & $13.8 \%$ \\
\hline
\end{tabular}

\subsection{Fatigue Crack Propagation: Residual Lifetime}

In comparison to grade 92 (Figure 7) it takes 1.25 times (to 316L 1.4 times) the stress intensity to initiate propagation of pre-existing cracks in HiperFer 17Cr2 (RX + PA), while MarBN even ranges slightly higher. Nevertheless stable crack propagation is at least half an order of magnitude faster in both the AFM steels and 316L, with rising advantage of HiperFer towards increasing stress intensity. Obviously, HiperFer does not display a classical "Paris-Erdogan" [53,54] regime of positive linear proportionality of crack growth velocity $(\mathrm{da} / \mathrm{dN})$ to rising stress intensity $(\Delta \mathrm{K})$ in a double logarithmic representation (Figure 7). It rather reflects staircase-like curve shape with plateau regions of constant, to some extent even slightly negative proportionality (indicated by the dashed-dotted lines, inserted into the HiperFer graph in Figure 7). Crack propagation in HiperFer thus remains at a constant, sometimes even decreasing, velocity over a comparatively wide range of the cyclic crack growth curve, despite of increasing stress intensity.

The proposed reason for this behavior is a combination of "reactive precipitation strengthening", outlined in the previous section, with several other aspects: The material "dynamically" hardens, because of cyclic, plastic material distortion in front of the crack tip, what aggravates crack propagation. Another contribution stems from low-angle grain boundaries, evolving in the plastic zone in front of the crack tip (cf. sub-grain formation, caused by accumulated creep deformation, in PFZs of crept specimens, cf. Section 3.4.1, Figure 11) and rapidly becoming decorated by Laves phase particles, which frequently lead to crack branching and thus dissipation of energy away from the main crack path. Pre-existing high angle grain boundaries, covered by Laves phase particles, act in the same way. 
A crack tip getting arrested at obstacles like particle clusters, (newly created) low- or (pre-existing) high-angle grain boundaries, causes increased stress intensity, in turn rising plastic distortion and consequently boosted precipitation, until a certain threshold is overcome and the crack tip breaks loose. It may further be assumed, that repetition of this mechanism causes the staircase-like curve shape in contrast to a classical Paris-Erdogan behavior. The detailed mechanism is not yet fully understood and still under investigation.

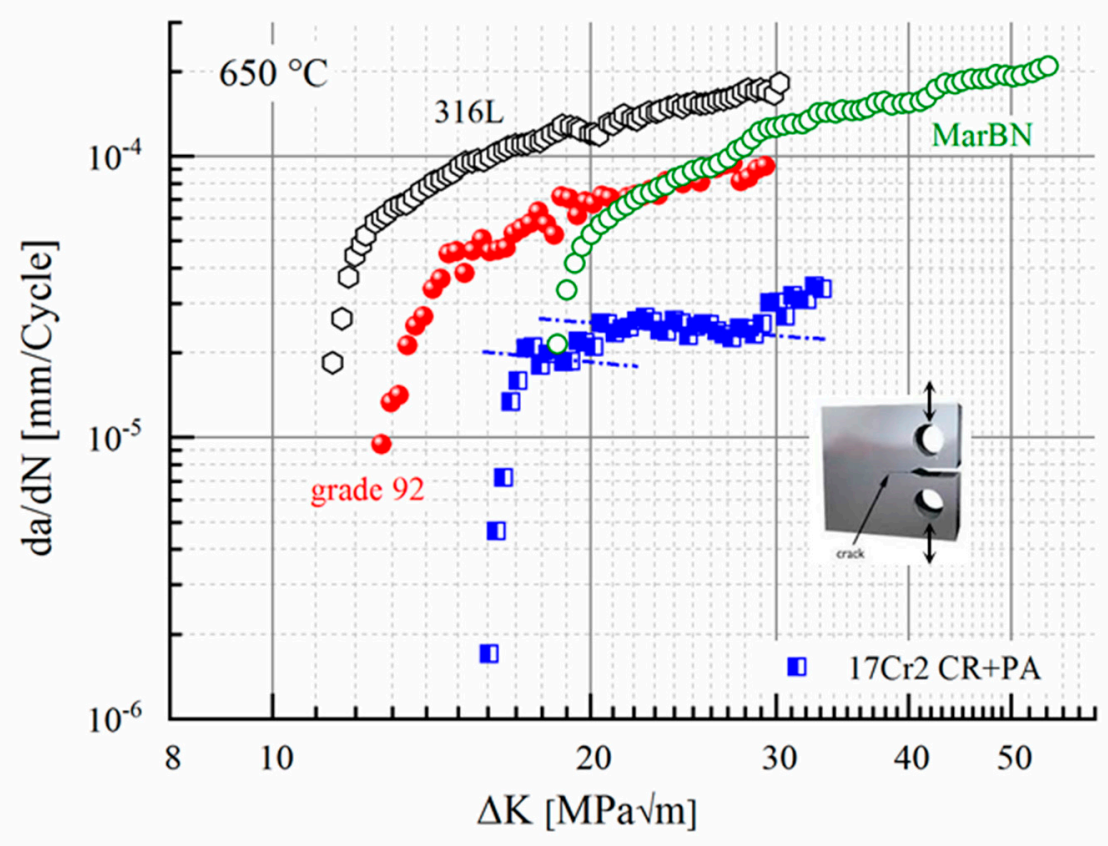

Figure 7. Cyclic crack growth curves $\left(650^{\circ} \mathrm{C}, \mathrm{f}=20 \mathrm{~Hz}, \mathrm{R}=0.1\right)$ of grade 92 , MarBN, 316 $\mathrm{L}$ and HiperFer $17 \mathrm{Cr} 2(\mathrm{CR}+\mathrm{PA})$.

\subsection{Creep}

\subsubsection{Characteristics: Low-vs. High-Alloying Variant}

The hot-rolled, low-alloy variant 17Cr1 yields comparably poor creep strength at intermediate and high creep stresses (> $100 \mathrm{MPa}$; cf. 17Cr1 HR in Figures 8-10), because of low dislocation density and a lack of strengthening precipitates, when put into service in the hot-rolled state. Nevertheless, it obviously approaches the grade 92 level at practically more relevant testing stresses lower than $100 \mathrm{MPa}$ (Figure 10). Cold-rolling not only yields increased tensile (cf. 17Cr2 CR in Figure 3a), but diminished minimum creep rate (Figure 9) and boosted creep rupture strength (Figures 8 and 10).

In creep, increased dislocation density has a two-fold effect in HiperFer steel: First, it accelerates precipitation and second, it sufficiently strengthens the material against creep deformation during the precipitation process. In combination, this leads to rapid establishment of a stable precipitate microstructure, reduced strain over the entire (mainly in the primary stage of) creep life (Figure 8a) and by this to a leap in creep rupture strength (Figures 8a and 10). A similar effect can be achieved by precipitation annealing of recrystallized material (cf. $100 \mathrm{MPa}$ values of 17Cr2 RX + PA in Figure 8a). Compared to cold-rolling, precipitation annealing after recrystallization leads to increased primary creep strain, but in turn to a slight decrease in minimum creep rate (cf. Figure 9) and finally further improved creep rupture life (Figures $8 \mathrm{a}$ and 10). The higher $\mathrm{W} / \mathrm{Nb}$ - contents boost solid solution and precipitation strengthening in case of the $17 \mathrm{Cr} 5$ composition, what in turn provides advanced creep strength. Except of increased primary stage creep strain (Figure 8b) the material performs almost comparable, no matter if put into service in the recrystallized $(\mathrm{RX})$ or recrystallized + precipitation 
annealed (RX + PA) state (Figures $8 b, 9$ and 10). Effective age-hardening characteristics thus were achieved and the design goal of $17 \mathrm{Cr} 5$ successfully met.

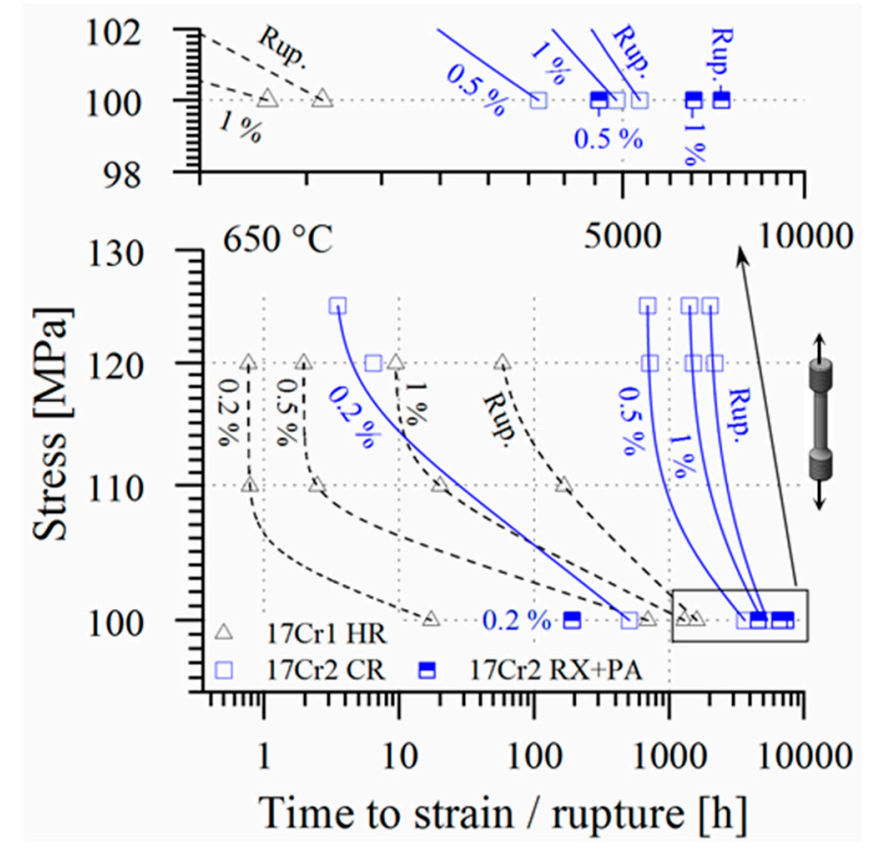

(a)

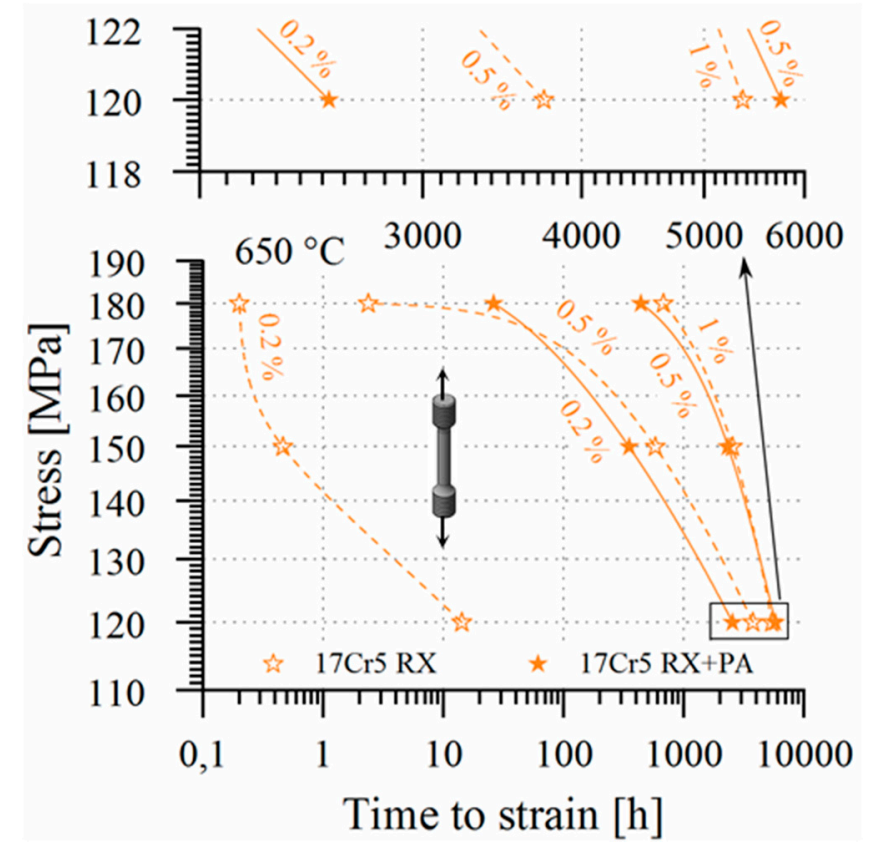

(b)

Figure 8. Impact of processing and heat-treatment state: Time to strain curves of hot-rolled 17Cr1, cold-rolled 17Cr2, recrystallized and precipitation annealed 17Cr2 (100 MPa data available only) (a), recrystallized and recrystallization and precipitation annealed $17 \mathrm{Cr} 5$ steel (b). 


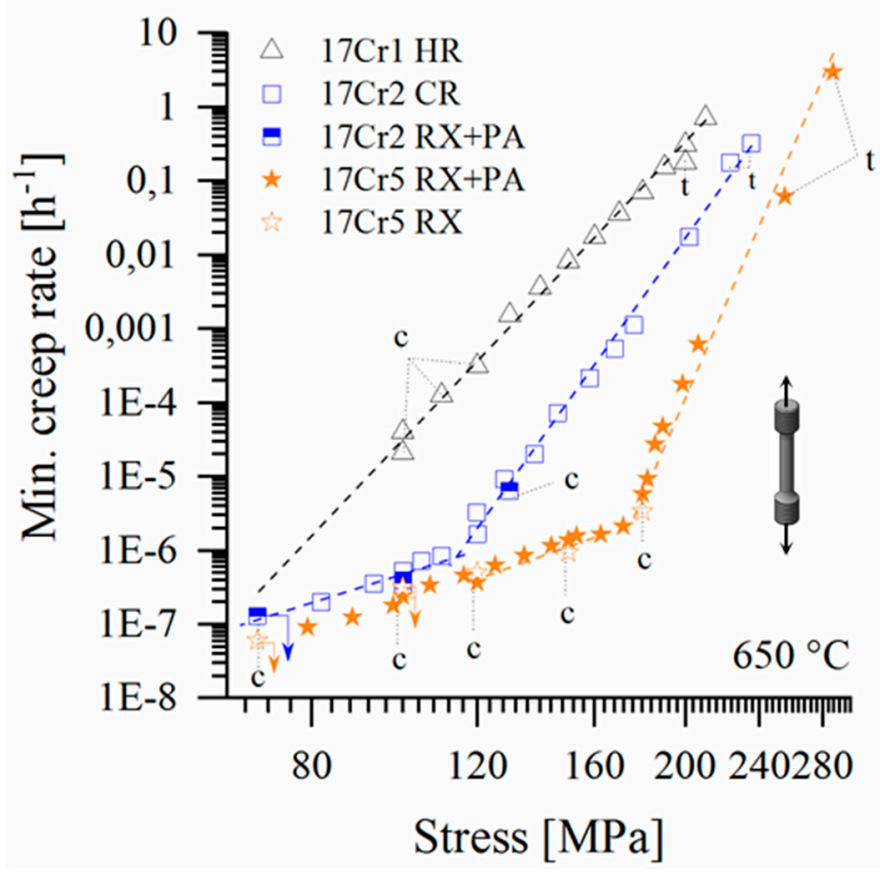

Figure 9. Norton-Bailey plot of the model steels in different processing and heat treatment states $\left(650{ }^{\circ} \mathrm{C}\right.$; data indexed by " $\mathrm{t}$ " $/$ " $\mathrm{c}$ " from tensile (UTS value)/uniaxial creep experiments, all others from stress relaxation testing; experiments marked with arrows are still in progress).

The change implemented in processing, from hot-rolling in case of $17 \mathrm{Cr} 1$ to cold-rolled $17 \mathrm{Cr} 2$, has a remarkable impact on the Norton-Bailey relations $[55,56]$ of the steels (Figure 9). In comparison to the low dislocation density, hot-rolled $17 \mathrm{Cr} 1$ material the high dislocation density, cold-rolled $17 \mathrm{Cr} 2$ steel yields minimum creep rates, diminished by at least an order of magnitude over the whole stress range. The minimum creep rates of recrystallized and precipitation annealed $17 \mathrm{Cr} 2$ material fits well into the data of the cold-rolled steel (Figure 9). High initial dislocation density or precipitation annealing are obviously very effective in decreasing the minimum creep rates of the low alloyed model steel variant. Synopsis of the results obtained so far suggests, that the impact of thermomechanical processing (i.e., mainly initial dislocation density) may practically fade out below a stress level of approximately $70 \mathrm{MPa}$ (cf. Figure 9: intersection of the extrapolated 17Cr1 HR line towards lower stress). Below this stress level (i.e., at practically relevant creep stress) / beyond this exposure time the thermomechanical treatment history is supposed to have no significant influence on creep life anymore.

\subsubsection{Creep Rupture Strength}

In Figure 10 the creep strength of the HiperFer $17 \mathrm{Cr} 2$ steels is ranked against various state of the art power engineering structural grades. Cold-rolled and recrystallization + precipitation annealed $(R X+$ PA) 17Cr2 surpasses grade 92 [57] and approximately matches the performance of the novel $12 \mathrm{Cr}$ steel Super VM12 [58]. While creep deformation of intermetallic particle strengthened HiperFer is controlled by growth of the strengthening Laves phase precipitates [16,47,59,60], creep damage and failure are mainly related to the accumulation of plastic deformation in PFZs (cf. Figure 11), evolving along high angle grain boundaries [36,47], in long-term application. Intragranular solid solution strengthening and particle volume fraction, as well as grain boundary particle coverage, were successfully increased and PFZ width alongside grain boundaries diminished in the $17 \mathrm{Cr} 5$ variant. 


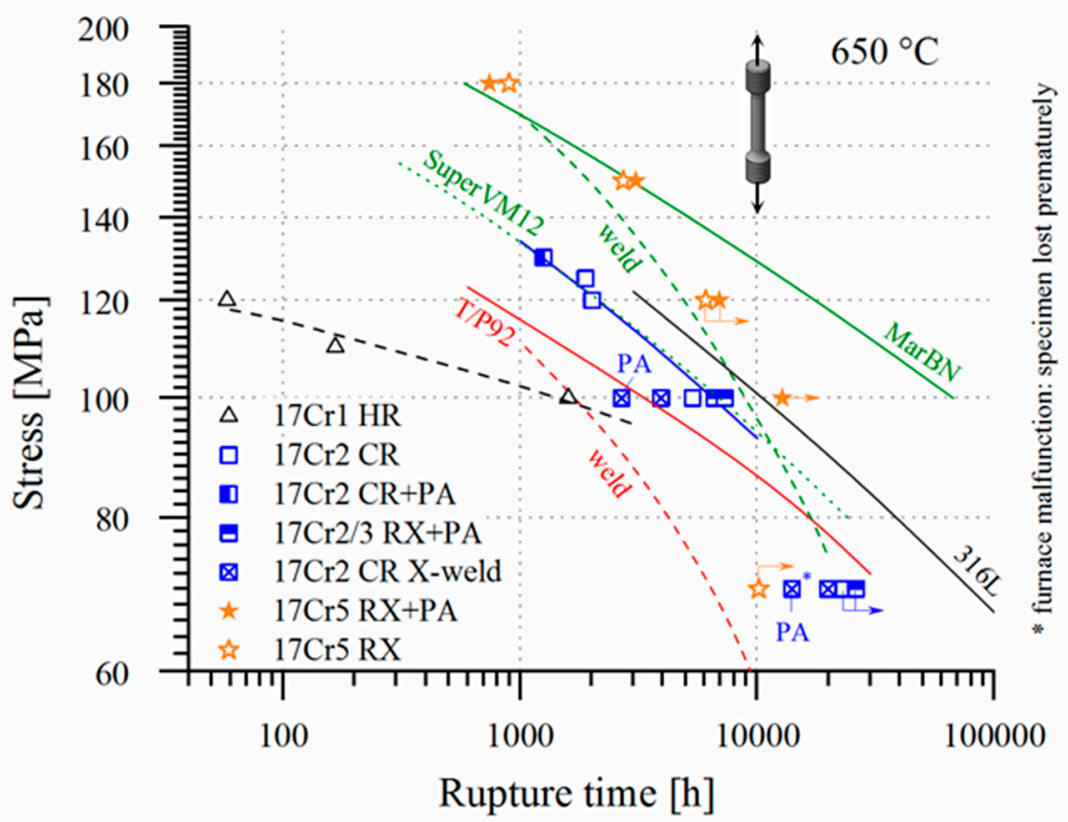

Figure 10. Creep rupture strength of HiperFer $17 \mathrm{Cr} 1 / 2$ and $17 \mathrm{Cr} 5$ in comparison to state of the art AFM and austenitic steels (100 MPa cross-weld data courtesy of Y. Yamamoto, ORNL, USA; comparative creep strength data: grade 92, 316L [57]; MarBN, mean of [61,62]; Super VM12 [58]; experiments marked with arrows are still in progress).

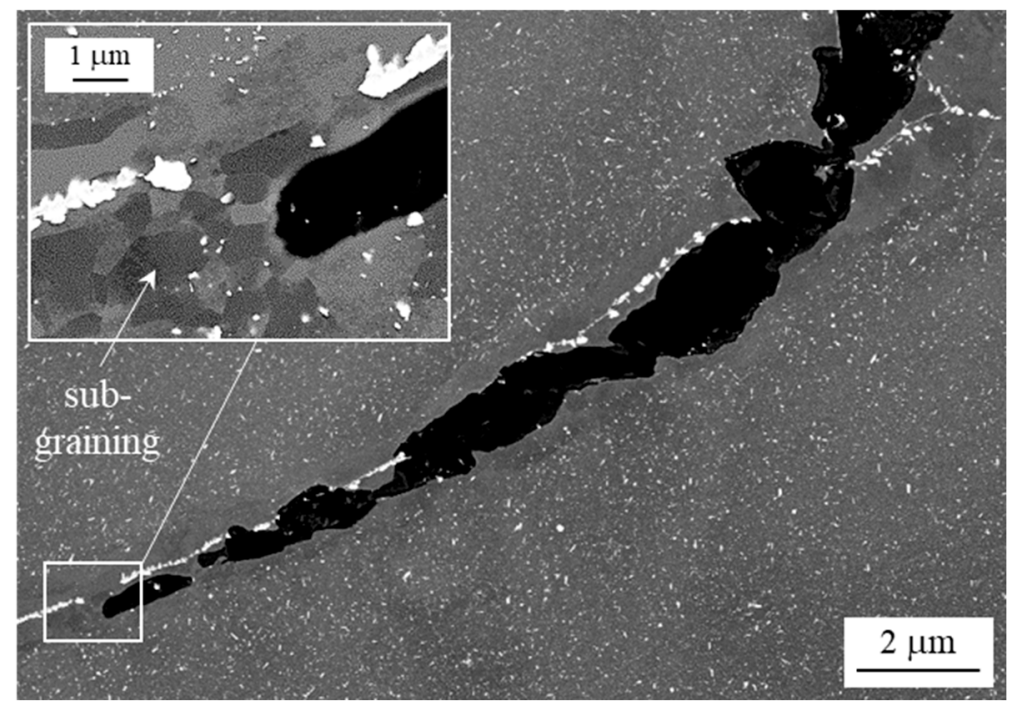

Figure 11. Accumulated plastic deformation, causing sub-grain formation (cf. inlay micrograph) and associated creep failure within PFZs, located at high angle grain boundaries of $17 \mathrm{Cr} 5 \mathrm{RX}$ material $\left(650{ }^{\circ} \mathrm{C}, 150 \mathrm{MPa}, \mathrm{t}_{\mathrm{R}}=2720 \mathrm{~h}\right.$, cf. Figure 10).

The results obtained on this improved alloy variant so far, at least at high stress (150 to $180 \mathrm{MPa}$; < $150 \mathrm{MPa}$ : in progress), suggest a creep strength on the MarBN-type [61,62] level. At intermediate stresses (150 to $100 \mathrm{MPa}$, experiments still in progress) it surpasses austenitic 316L steel [57]. Nevertheless further data is necessary on lower stress levels.

First, manually produced gas tungsten arc welded (GTAW) joints of cold-rolled base material were produced, applying chemically identical filler metal strips, taken from the base metal plate. Like outlined in Section 2.3 these welds intentionally represent the worst-case of deformed (i.e., as-rolled, forged, bent,) material, being welded and put into service without conventional AFM-like post-weld 
heat treatment (PWHT, i.e., annealing above application temperature). At an intermediate stress level of $100 \mathrm{MPa}$ cold-rolled HiperFer 17Cr2 (CR X-weld) in the as-welded state yields rupture time slightly below, but performing simplified precipitation annealing (cf. Section 2.4) after welding pushes the weld above the grade 92 base metal level (PA in Figure 10). At low stress (70 MPa) it outplays welded grade 92 (including PWHT) by far. The precipitation annealed weld even yielded creep lifetime in the extrapolated range of MarBN-type welds. Unfortunately, the as-welded $70 \mathrm{MPa}$ creep specimen was prematurely lost, because of a furnace malfunction. Creep rupture of all the $100 \mathrm{MPa}$ cross-weld specimens appeared in the weld metal, while the precipitation treated $70 \mathrm{MPa}$ specimen ruptured in the heat affected zone after $19879 \mathrm{~h}$. The transition in fracture location is subject of further investigation.

Ease of monitoring is mandatory for high temperature structural materials. A combination of sufficient duration of tertiary creep and rupture deformation is desired. By and large the 17Cr2 (CR and RX + PA states) and 17Cr5 (RX and RX + PA states) alloys obey similar, time-modified Monkman-Grant [63] relations of time to minimum creep rate to time to rupture [64]. These indicate that more than $70 \%$ of creep life lies within the short secondary and predominantly the tertiary stage of creep. For this reason, creep life of HiperFer steel can be monitored according to the common codes of conduct.

\subsection{Stress Relaxation}

For materials utilized in bolting application resistance to stress relaxation is an important prerequisite. Figure 12 displays stress relaxation curves of the cold-rolled $17 \mathrm{Cr} 2$ and $\mathrm{RX}+\mathrm{PA} 17 \mathrm{Cr} 5$ steels in comparison to ferritic-martensitic grade 92. A remaining stress level of $115 \mathrm{MPa}$ after $600 \mathrm{~h}$ of relaxation at $600{ }^{\circ} \mathrm{C}$ is a benchmark value to reach for novel materials [65], when initiating stress relaxation from $250 \mathrm{MPa}$. With remaining stresses falling below $115 \mathrm{MPa}$ after $7 / 312 \mathrm{~h} 17 \mathrm{Cr} 2 \mathrm{CR}$ and $17 \mathrm{Cr} 5 \mathrm{RX}+\mathrm{PA}$ fail to reach this criterion in the first relaxation (Figure 12a). Nevertheless, the HiperFer grades perform remarkably better than grade 92 , which drops to about $30 \mathrm{MPa}$ within $87 \mathrm{~h}$, while the ferritic model steels stabilize at around $95 \mathrm{MPa}$ after $30 \mathrm{~h}$ in case of $17 \mathrm{Cr} 2 \mathrm{CR}$ and $468 \mathrm{~h}$ in case of $17 \mathrm{Cr} 5$ $\mathrm{RX}+\mathrm{PA}$. After reloading all the HiperFer materials perform better in the second run. $17 \mathrm{Cr} 2 \mathrm{CR}$ fails the criterion after another $309 \mathrm{~h}$, while grade 92 after $45 \mathrm{~h}$ already. 17Cr5 RX + PA stabilizes well above the criterion (in a range from 150-160 MPa) for another $600 \mathrm{~h}$. Thermomechanically induced precipitation of consecutive populations of Laves phase particles upon reloading is argued to be the cause for the gradual increase in performance of the HiperFer grades.

After termination of the second runs, the specimens were heated to $650{ }^{\circ} \mathrm{C}$ under the load level reached upon termination. A further relaxation run was then started after loading to $200 \mathrm{MPa}$. At $650{ }^{\circ} \mathrm{C}$ the criteria to meet are $>95 \mathrm{MPa}$ after $100 \mathrm{~h},>55 \mathrm{MPa}$ after $1000 \mathrm{~h}$ and $>40 \mathrm{MPa}$ after $3000 \mathrm{~h}$ (initial stress level: $200 \mathrm{MPa}$ ) [65]. The grade 92 specimen fails the $100 \mathrm{~h}$ criterion in two consecutive runs (Figure $12 \mathrm{~b}$ : after $4 / 23 \mathrm{~h}$ in the $3^{\text {rd }} / 4^{\text {th }}$ run). In contrast to this $17 \mathrm{Cr} 2 \mathrm{CR}$ meets the $100 \mathrm{~h}$ criterion and reaches $78 \mathrm{MPa}$ after another $514 \mathrm{~h}$ in the third run. Applying the stress relaxation rate at termination $\left(0.0266 \mathrm{MPah}^{-1}\right)$ and linearly extrapolating to $1000 \mathrm{~h}$ a resulting stress level of 65 $\mathrm{MPa}$ would have been reached and the criterion (> $55 \mathrm{MPa}$ ) successfully met. The third run of $17 \mathrm{Cr} 5$ $\mathrm{RX}+\mathrm{PA}$ was terminated after $2347 \mathrm{~h}$ at a stress level of $70 \mathrm{MPa}$. By applying the stress relaxation rate at termination $\left(0.0114 \mathrm{MPah}^{-1}\right)$, it is apparent, that the $3000 \mathrm{~h}$ criterion would have been fulfilled. HiperFer can be thus considered as a potential candidate material for bolting application. Nevertheless, further investigation into heat treatment, concerning stabilization of early stage relaxation performance is needed. 


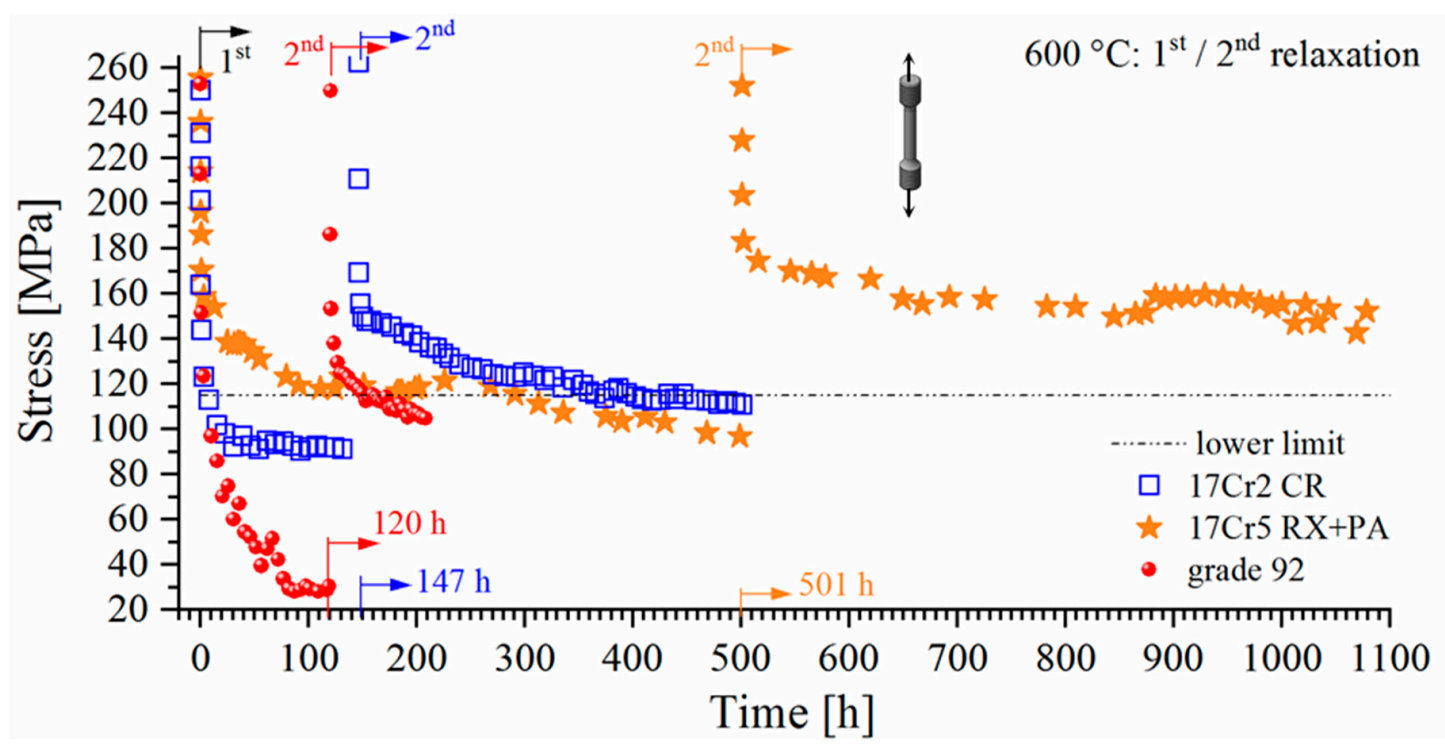

(a)

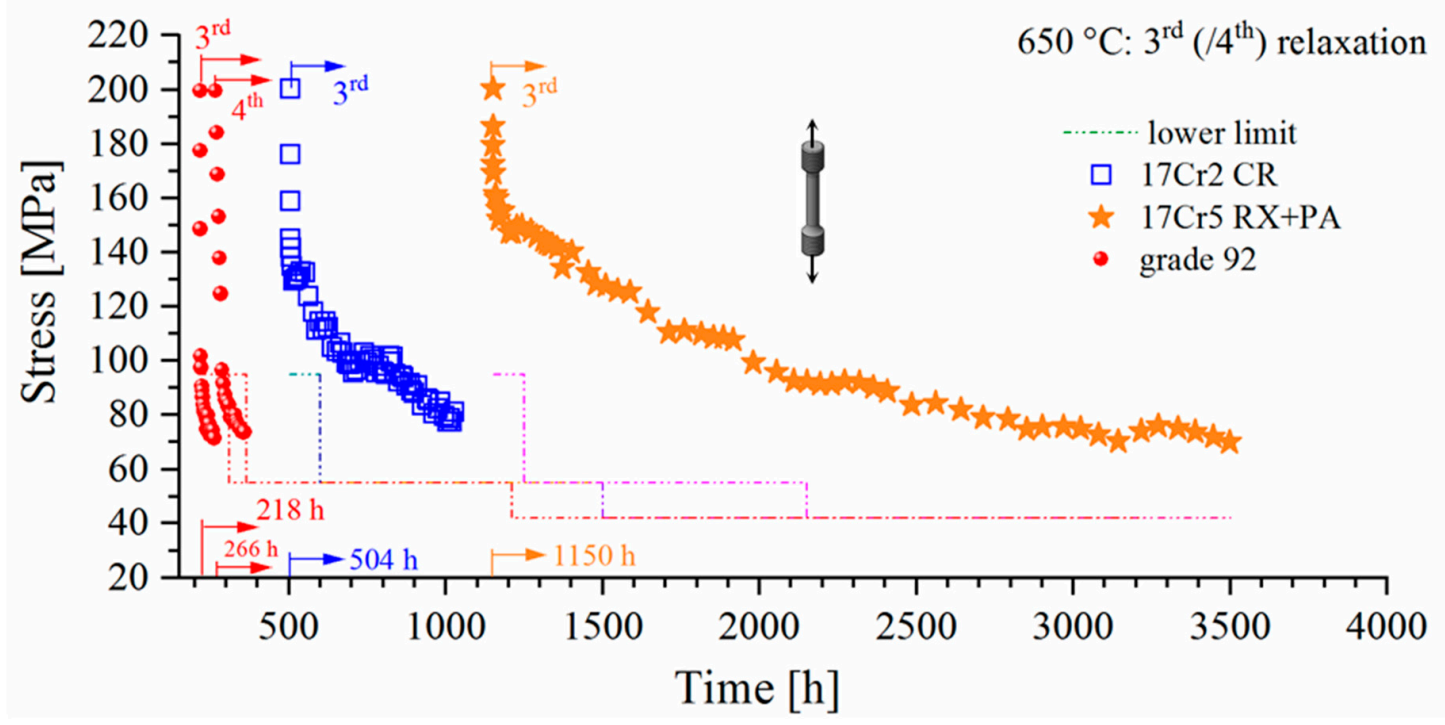

(b)

Figure 12. Stress relaxation of cold-rolled $17 \mathrm{Cr} 2$ and $\mathrm{RX}+\mathrm{PA} 17 \mathrm{Cr} 5$ material in comparison to ferritic-martensitic grade $92,\left(\right.$ a) $1^{\text {st }}+2^{\text {nd }}$ run: $600{ }^{\circ} \mathrm{C}$ (initial stress level: $250 \mathrm{MPa}$ ) and (b) $3^{\text {rd }}+\left(4^{\text {th }}\right.$ ) run: $650{ }^{\circ} \mathrm{C}$ (initial stress level: $200 \mathrm{MPa}$ ).

\subsection{Charpy Impact Strength}

Relevant technical rules [66] dictate minimum impact energy values of $27 / 40 \mathrm{Jcm}^{-2}$ (longitudinal/transversal direction) at ambient temperature (indicated in Figure 13). The impact strength of ferritic, high chromium, stainless steel is generally considered problematic. If proper processing and heat treatment are applied, this can be avoided [67]. Figure 13 displays brittle to ductile transition curves of the $17 \mathrm{Cr} 2(\mathrm{RX}+\mathrm{PA})$ and $17 \mathrm{Cr} 5(\mathrm{RX})$ variants. Recrystallized and precipitation annealed $17 \mathrm{Cr} 2(\mathrm{RX}+\mathrm{PA})$ steel yields a steep transition curve, a DBTT of $-11^{\circ} \mathrm{C}$ and high upper shelf energy (all typical for quenched ferritic stainless steels [68]) and thus meets the technical specifications. 


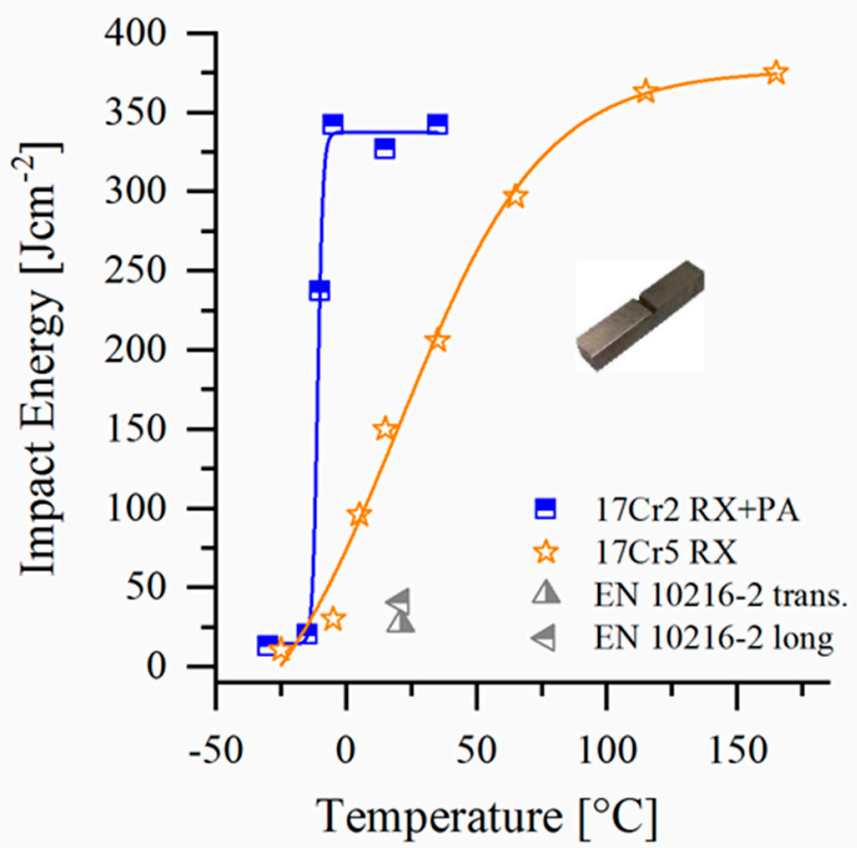

Figure 13. Impact strength of the recrystallized and precipitation annealed ( $R X+P A) 17 C r 2$ and recrystallized $(\mathrm{RX}) 17 \mathrm{Cr} 5$ steels (each data point represents the mean of three measurements).

Recrystallized 17Cr5 (RX) exhibits a less steep curve and a DBTT value of $31^{\circ} \mathrm{C}$ and fulfills the requirements, too. The $17 \mathrm{Cr} 5$ material was recrystallized at comparatively high temperature $\left(1100-1125^{\circ} \mathrm{C}\right)$ and for this reason prevails in larger grain size, which typically results in a decrease in DBTT curve slope [69]. The correlations between chemical composition, processing, heat treatment, resulting microstructure and impact toughness of ferritic stainless steels are complex. For detailed information [67] may be consulted.

\section{Conclusions}

Based on its high chromium content and unique strengthening by thermally/thermomechanically induced $(\mathrm{Fe}, \mathrm{Cr}, \mathrm{Si})_{2}(\mathrm{Nb}, \mathrm{W})$-Laves phase precipitation, HiperFer steel combines superior steam oxidation and wet corrosion resistance with improved mechanical properties. The $17 \mathrm{Cr} 2(2.5 \mathrm{~W}-0.6 \mathrm{Nb})$ steel combines supreme thermomechanical fatigue strength and resistance to fatigue crack propagation, promising creep / cross-weld creep and viable tensile and Charpy impact properties. The high-alloyed $17 \mathrm{Cr} 5(3.7 \mathrm{~W}-1 \mathrm{Nb})$ variant provides effective age-hardening capability, offers increased thermomechanical fatigue resistance and creep strength potentially combating the strongest AFM steels available. HiperFer can thus be considered as a high potential, low cost candidate material for tubing, piping, blading and bolting applications in flexibly operated, future power conversion equipment like pumped thermal electricity storage (i.e., Carnot batteries ), concentrating solar power or power-2-X conversion systems and conventional back-up power plants. Future research will concentrate on optimized processing, broadening the mechanical property database, detailed understanding and full exploitation of the "reactive hardening" mechanisms and PFZ engineering to optimize the performance of this novel steel category.

Author Contributions: Conceptualization, B.K., M.T. and Y.Y.; methodology, B.K., M.T. and Y.Y.; software, M.T., X.F.; validation, B.K., M.T., T.F. and J.L.B.; formal analysis, B.K., M.T., T.F., X.F., J.L.B.; investigation, B.K., M.T., Y.Y., T.F., X.F. and J.L.B.; resources, B.K. and Y.Y.; data curation, B.K., M.T., Y.Y. and T.F.; writing-original draft preparation, B.K.; writing-review and editing, Y.Y. and T.F.; visualization, B.K. and T.F.; supervision, B.K. and Y.Y.; project administration, B.K. and Y.Y.; funding acquisition, B.K. and Y.Y. All authors have read and agreed to the published version of the manuscript. 
Funding: This research was funded by the German Ministry of Education and Research under grant number 03EK3032. Y. Yamamoto's welding research was sponsored by the U.S. Department of Energy, Office of Fossil Energy, the Crosscutting Research Program, under contract DE-AC05-00OR22725 with UT-Battele, LLC.

Acknowledgments: The authors would like to express their gratitude for open discussions and ideas concerning the production and processing of the HiperFer trial steels to H.-H. Dickert*, A. Stieben*, M. Schulte*, W. Bleck ${ }^{*}$ and G. Hessling ((*former affiliation) Steel Institute, RWTH Aachen University, Aachen, Germany). Supply of MarBN type steel for experimental purpose by T. U. Kern (Siemens Power and Gas) is acknowledged.

Conflicts of Interest: The authors declare no conflict of interest. The funders had no role in the design of the study; in the collection, analyses, or interpretation of data; in the writing of the manuscript, or in the decision to publish the results.

\section{References}

1. Laughlin, R.B. Pumped thermal grid storage with heat exchange. J. Renew. Sustain. Energy 2017, 9, 044103. [CrossRef]

2. Steinmann, W.D.; Jockenhöfer, H.; Bauer, D. Thermodynamic Analysis of High-Temperature Carnot Battery Concepts. Energy Technol. 2019, 1900895, 1-13. [CrossRef]

3. Hoffschmidt, B.; Alexopoulos, S.; Göttsche, J.; Sauerborn, M.; Kaufhold, O. High Concentration Solar Collectors. In Comprehensive Renewable Energy; Elsevier: Amsterdam, The Netherlands, 2012; pp. 167-207.

4. Santos, J.J.C.S.; Palacio, J.C.E.; Reyes, A.M.M.; Carvalho, M.; Freire, A.J.R.; Barone, M.A. Advances in Renewable Energies and Power Technologies. In Solar and Wind Energies; Elsevier: Amsterdam, The Netherlands, 2018; pp. 373-402.

5. Roeb, M.; Monnerie, N.; Houaijia, A.; Thomey, D.; Sattler, C. Solar Thermal Water Splitting. In Renewable Hydrogen Technologies; Elsevier: Amsterdam, The Netherlands, 2013; pp. 63-84.

6. Abe, F.; Kern, T.U.; Viswanathan, R. Alloy design philosophies of creep-resistant steel. In Creep Resistant Steels; Woodhead Publishing Limited: Cambridge, UK, 2008; pp. 541-570.

7. Viswanathan, R.; Bakker, W. Materials for ultrasupercritical coal power plants-Boiler materials: Part 1. J. Mater. Eng. Perform. 2001, 10, 81-95. [CrossRef]

8. Abe, F. Bainitic and martensitic creep-resistant steels. Curr. Opin. Solid State Mater. Sci. 2004, 8, 305-311. [CrossRef]

9. Danielsen, H.K.; Hald, J. Behaviour of Z phase in 9-12\% Cr steels. Energy Mater. 2006, 1, 49-57. [CrossRef]

10. Danielsen, H.K.; Hald, J. Influence of Z-phase on Long-term Creep Stability of Martensitic 9 to $12 \%$ Cr Steels. VGB Power Tech. 2009, 5, 68-73.

11. Quadakkers, W.J.; Zurek, J. Oxidation in Steam and Steam/Hydrogen Environments. In Shreir's Corrosion, 4th ed.; Cottis, B., Graham, M., Lindsay, R., Lyon, S., Richardson, T., Scantlebury, D., Scott, H., Eds.; Elsevier: Amsterdam, The Netherlands, 2010; Volume 1, pp. 407-456.

12. Wright, I.G.; Dooley, R.B. A review of the oxidation behaviour of structural alloys in steam. Int. Mater. Rev. 2010, 55, 129-167. [CrossRef]

13. Wagner, R.; Czempik, E. Konservierung von Kesselanlagen und Turbinen mit dem grenzflächenaktiven Stoff Octadecylamin. VGB Power Tech. 2014, 3, 48-51.

14. Kuhn, B.; Talik, M. HiperFer-High Performance Ferritic Steels. In Proceedings of the 10th Liége Conference on Materials for Advanced Power Engineering, Liége, Belgium, 14-17 September 2014; pp. 264-273.

15. Lopez Barrilao, J.; Kuhn, B.; Wessel, E. Microstructure and Intermetallic Particle Evolution in Fully Ferritic Steels. In Proceedings of the 8th International Conference on Advances in Materials Technology for Fossil Power Plants, Albufeira, Portugal, 11-14 October 2016; pp. 1027-1035.

16. Kuhn, B.; Talik, M.; Niewolak, L.; Zurek, J.; Hattendorf, H.; Ennis, P.J. Development of high chromium ferritic steels strengthened by intermetallic phases. Mater. Sci. Eng. A 2014, 594, 372-380. [CrossRef]

17. Kuhn, B.; Talik, M.; Lopez Barrilao, J.; Singheiser, L. Microstructure stability of ferritic-martensitic, austenitic and fully ferritic steels under fluctuating loading conditions. In Proceedings of the 1st 123 HiMat Conference on Advanced High-Temperature Materials Technology for Sustainable and Reliable Power Engineering (123HiMAT-2015), Sapporo, Japan, 29 June-3 July 2015; pp. 94-97. 
18. Kuhn, B.; Lopez Barrilao, J.; Fischer, T. "Reactive” Microstructure: The Key to Cost Effective, Fatigue Resistant High Temperature Structural Materials. In Proceedings of the EPRI's 9th International Conference on Advances in Materials Technology for Fossil Power Plants and the 2nd International 123HiMAT Conference on High-Temperature Materials, Nagasaki, Japan, 21-25 October 2019; pp. 1-10.

19. Okamoto, H.; Schlesinger, M.E.; Mueller, E.M. (Eds.) Introduction to Alloy Phase Diagrams. In ASM Hand Book; ASM International: Materials Park, OH, USA, 2016; Volume 3, p. 8.

20. Fujita, N.; Ohmura, K.; Yamamoto, A. Changes of microstructures and high temperature properties during high temperature service of Niobium added ferritic stainless steels. Mater. Sci. Eng. A 2003, 351, 272-281. [CrossRef]

21. Oono, N.; Nitta, H.; Iijima, Y. Diffusion of niobium in $\alpha$-iron. Mater. Trans. 2003, 44, 2078-2083. [CrossRef]

22. Herzig, C.; Geise, J.; Divinski, S.V. Niobium bulk and grain boundary diffusion in alpha-iron. Z. Metallk. 2002, 93, 1180-1187. [CrossRef]

23. Sim, G.M.; Ahn, J.C.; Hong, S.C.; Lee, K.J.; Lee, K.S. Effect of Nb Precipitate Coarsening on the High Temperature Strength in Nb Containing Ferritic Stainless Steels. Mater. Sci. Eng. A 2005, 396, $159-165$. [CrossRef]

24. Hosoi, Y.; Wade, N.; Kunimitsu, S.; Urita, T. Precipitation behavior of Laves phase and its effect on toughness of 9Cr-2Mo Ferritic-martensitic steel. J. Nucl. Mater. 1986, 141, 461-467. [CrossRef]

25. Suo, J.; Peng, Z.; Yang, H.; Chai, G.; Yu, M. Formation of Laves Phase in Sanicro 25 Austenitic Steel during Creep-Rupture Test at $700{ }^{\circ} \mathrm{C}$. Metallogr. Microstruct. Anal. 2019, 2, 281-286. [CrossRef]

26. Aghajani, A.; Richter, F.; Somsen, C.; Fries, S.G.; Steinbach, I.; Eggeler, G. On the formation and growth of Mo-rich Laves phase particles during long-term creep of a $12 \%$ chromium tempered martensite ferritic steel. Scr. Mater. 2009, 61, 1068-1071. [CrossRef]

27. Guo, J.T.; Zhou, L.Z. The Effect of Phosphorus, Sulphur and Silicon on Segregation, Solidification and Mechanical Properties of Cast Alloy 718. In Proceedings of the 8th International Symposium on Superalloys, Seven Springs Mountain Resort, Champion, PA, USA, 22-26 September 1996; pp. 451-458.

28. Kato, Y.; Ito, M.; Kato, Y.; Furukimi, O. Effect of Si on Precipitation Behavior of Nb-Laves Phase and Amount of $\mathrm{Nb}$ in Solid Solution at Elevated Temperature in High Purity $17 \% \mathrm{Cr}-0.5 \% \mathrm{Nb}$ Steels. Mater. Trans. 2010, 51, 1531-1535. [CrossRef]

29. Froitzheim, J.; Meier, G.H.; Niewolak, L.; Ennis, P.J.; Hattendorf, H.; Singheiser, L. Development of high strength ferritic steel for interconnect application in SOFCs. J. Power Sources 2008, 178, 163-173. [CrossRef]

30. Niewolak, L.; Savenko, A.; Grüner, D.; Hattendorf, H.; Breuer, U.; Quadakkers, W.J. Temperature Dependence of Laves Phase Composition in $\mathrm{Nb}, \mathrm{W}$ and Si-Alloyed High Chromium Ferritic Steels for SOFC Interconnect Applications. JPEDAV 2015, 36, 471-484. [CrossRef]

31. Tanczyn, H. Ferritic Stainless Steel. U.S. Patent 4,179,285, 27 July 1978.

32. Becket, F.M.; Franks, R.F. Chromium-containing steels. U.S. Patent 1,954,344, 10 April 1934.

33. Johnson, J.N. Influence of Columbium on the $870{ }^{\circ} \mathrm{C}$ creep properties of $18 \%$ chromium ferritic stainless steels. Sae Tech. Pap. Ser. 1981, 810035, 1-13.

34. Hsiao, B.; Kuhn, Z.W.; Chen, D.; Singheiser, L.; Kuo, J.C.; Lin, D.Y. Characterization of Laves phase in Crofer $22 \mathrm{H}$ stainless steel. Micron 2015, 74, 59-64. [CrossRef]

35. Shakhpazov, E.K.; Gordienko, A.I.; Zaitsev, A.I.; Rodionova, I.G.; Krylov-Olefirenko, V.V.; Shaposhnikov, N.G. Increase in the level of mechanical and other service properties of automobile sheet steels by controlling precipitation of nonmetallic excess phases. Metallurgist 2009, 53, 543-550. [CrossRef]

36. Kuhn, B.; Asensio Jimenez, C.; Niewolak, L.; Hüttel, T.; Beck, T.; Hattendorf, H.; Singheiser, L.; Quadakkers, W.J. Effect of Laves phase strengthening on the mechanical properties of high Cr ferritic steels for solid oxide fuel cell interconnect application. Mater. Sci. Eng. A 2011, 528, 5888-5899. [CrossRef]

37. Hsieh, C.C.; Wu, W. Overview of Intermetallic Sigma ( $\sigma)$ Phase Precipitation in Stainless Steels. Isrn Metall. 2012, 2012, 732471. [CrossRef]

38. Hsieh, C.C.; Lin, D.Y.; Wu, W. Precipitation behavior of $\sigma$ phase in $19 \mathrm{Cr}-9 \mathrm{Ni}-2 \mathrm{Mn}$ and $18 \mathrm{Cr}-0.75 \mathrm{Si}$ stainless steels hot-rolled at $800{ }^{\circ} \mathrm{C}$ with various reduction ratios. Mater. Sci. Eng. A 2007, 467, 181-189. [CrossRef]

39. Hsieh, C.C.; Wu, W. Discussing the precipitation behavior of $\sigma$ phase using diffusion equation and thermodynamic simulation in dissimilar stainless steels. Alloy. Compd. 2010, 506, 820-825. [CrossRef]

40. Garces, G.R.; Coze, J.; Le Garin, J.L.; Mannheim, R.L. $\sigma$-phase precipitation in two heat-resistant steels-Influence of carbides and microstructure. Scr. Mater. 2004, 50, 651-654. [CrossRef] 
41. Charles, J.; Mithieux, J.D.; Santacreu, P.O.; Peguet, L. The Ferritic Stainless Steel Family: The Appropriate Answer to Nickel Volatility? Rev. Met. Paris 2009, 106, 124-139. [CrossRef]

42. The Ferritic Solution-The Essential Guide to Ferritic Stainless Steels. International Stainless Steel Forum (ISSF). Available online: http://www.worldstainless.org/Files/issf/non-image-files/PDF/ISSF_The_Ferritic_ Solution_English.pdf (accessed on 4 March 2020).

43. ASTM E190-14, Standard Test Method for Guided Bend Test for Ductility of Welds; ASTM International: West Conshohocken, PA, USA, 2014.

44. Kuhn, B.; Talik, M.; Lopez Barrilao, J.; Yamamoto, Y. Development Status of High Performance Ferritic (HiperFer) Steels. In Proceedings of the 8th International Conference on Advances in Materials Technology for Fossil Power Plants, Albufeira, Portugal, 11-14 October 2016; pp. 1018-1026.

45. Abson, D.J.; Rothwell, J.S. Review of type IV cracking of weldments in 9-12\% Cr creep strength enhanced ferritic steels. Int. Mater. Rev. 2013, 58, 437-473. [CrossRef]

46. Francis, J.A.; Mazur, W.; Bhadeshia, H.K.D.H. Type IV cracking in ferritic power plant steels. Mater. Sci. Technol. 2006, 22, 1387-1395. [CrossRef]

47. Lopez Barrilao, J.; Kuhn, B.; Wessel, E. Microstructure evolution and dislocation behaviour in high chromium, fully ferritic steels strengthened by intermetallic Laves phases. Micron 2018, 108, 11-18. [CrossRef] [PubMed]

48. Hähner, P.; Affeldt, E.; Beck, T.; Klingelhöffer, H. Validated Code of Practice for Strain Controlled Thermomechanical Fatigue Testing 2006. Available online: https://www.researchgate.net/profile/Peter_ Haehner/publication/265152601_Validated_Code-of-Practice_for_Strain-Controlled_Thermo-Mechanical_ Fatigue_Testing/links/5447bd0f0cf2f14fb8123686.pdf (accessed on 4 March 2020).

49. ASTM E647-11, Standard Test Method for Measurement of Fatigue Crack Growth Rates; ASTM International: West Conshohocken, PA, USA, 2011.

50. Schill, R.; Forget, P.; Sainte Catherine, C. Correlation between Charpy-V and Subsize Charpy Test Results for an Un-Irradiated Low Alloy RPV Ferritic Steel. Available online: https://www.researchgate.net/ profile/Pascal_Galon2/publication/276468690_Finite_element_simulations_and_empirical_correlation_ for_Charpy-V_and_Subsize_Charpy_tests_on_an_unirradiated_low-alloy_RPV_ferritic_steel/links/ 59a8754fa6fdcc2398387a2c/Finite-element-simulations-and-empirical-correlation-for-Charpy-V-andSubsize-Charpy-tests-on-an-unirradiated-low-alloy-RPV-ferritic-steel.pdf (accessed on 4 March 2020).

51. Barret, R.; Donoghue, P.; Leen, S. A physically-based high temperature yield strength model for $9 \mathrm{Cr}$ steels. Mater. Sci. Eng. A 2018, 730, 410-424. [CrossRef]

52. Nieuwland, H.C.D.; Brunor, G.; Grosser, E.D.; Petrequin, P.; Vanderborck, Y.; Wood, D.S. Comparison of the Tensile Properties of 9-12\% Cr Steels (Pt1) Data Files, (Pt2) Final Report (EUR-9875); Commission of the European Communities (CEC): Luxembourg, 1985.

53. Paris, P.C.; Gomez, M.P.; Anderson, W.E. A rational analytic theory of fatigue. Trend Eng. 1961, 13, 9-14.

54. Paris, P.C.; Erdogan, F. A critical analysis of crack propagation laws. J. Basic Eng. 1963, 85, 528-533. [CrossRef]

55. Norton, F.H. The Creep of Steels at High Temperatures; Mc Graw-HilI: New York, NY, USA, 1929.

56. Bailey, R.W. Creep of Steel under Simple and Compound Stresses, and the Use of High Initial Temperature in Steam Power Plants. In Proceedings of the Transactions of the World Power Conference, Tokyo, Japan, 29 October-7 November 1929; Volume 3, p. 1089.

57. ECCC Datasheets 2014. ASTM Grade 92. 2014. Available online: https://www.scribd.com/document/ 293856994/Eccc-Data-Sheets-2014-i2r001 (accessed on 2 April 2020).

58. Subanović, M.; Pirón, J.; Zeller, F.; Jarrar, M.; Schneider, A. Development of a New High-Performance Martensitic Heat Resistant Steel for Boiler Applications. In Proceedings of the ASME 2018 Symposium on Elevated Temperature Application of Materials for Fossil, Nuclear, and Petrochemical Industries ETAM2018, Seattle, DC, USA, 3-5 April 2018.

59. Lopez Barrilao, J.; Kuhn, B.; Wessel, E.; Talík, M. Microstructure of intermetallic particle strengthened high-chromium fully ferritic steels. Mater. Sci. Technol. 2017, 33, 1056-1064. [CrossRef]

60. Lopez Barrilao, J.; Kuhn, B.; Wessel, E. Identification, size classification and evolution of Laves phase precipitates in high chromium, fully ferritic steels. Micron 2017, 101, 221-231. [CrossRef]

61. Abstoss, K.G.; Nitsche, A.; Mayr, P.; Schlacher, C.; Gonzales, V.; Aguero, A. Experience with 9Cr3W3CoVNbBN steel in terms of welding, creep and oxidation. In Proceedings of the 8th International Conference on Advances in Materials Technology for Fossil Power Plants, Albufeira, Portugal, 11-14 October 2016; pp. 989-1000. 
62. Hamaguchi, T.; Okada, H.; Semba, H.; Hirata, H.; Iseda, A.; Yoshizawa, M. Development of High Strength 9Cr-3W-3Co-Nd-B Heat Resistant Steel Tube and Pipe. In Proceedings of the 1st 123 HiMat Conference on Advanced High-Temperature Materials Technology for Sustainable and Reliable Power Engineering (123HiMAT-2015), Sapporo, Japan, 29 June-3 July 2015; pp. 114-117.

63. Monkman, F.; Grant, N. An Empirical Relationship between Rupture Life and Minimum Creep Rate in Creep-Rupture Tests. ASTM Proc. 1956, 56, 593-620.

64. Kuhn, B.; Yamamoto, Y.; Talik, M.; Lopez Barrilao, J. High Performance Ferrite (HiperFer)—A New Alloy Family. In Proceedings of the 4th International ECCC Creep \& Fracture Conference, Duesseldorf, Germany, 10-14 September 2017.

65. Personal Email Communication with Dr. T.-U. Kern, Siemens Energy Sector, Mülheim a. d. Ruhr, Germany. Available online: http:/www.entech.rs/PDF/STANDARDS\%20DATA\%20SHEETS/STEEL\%20EN/ EN\%2010216-2.pdf (accessed on 1 April 2020).

66. European Standard EN 10216-2: Seamless Steel Tubes for Pressure Purposes -Technical Delivery Conditions-Part 2: Non-Alloy and Alloy Steel Tubes with Specified Elevated Temperature Properties. Available online: http://www.entech.rs/PDF/STANDARDS\%20DATA\%20SHEETS/STEEL\%20EN/EN\% 2010216-2.pdf (accessed on 1 April 2020).

67. Wright, R.N. Toughness of Ferritic Stainless Steels. In Toughness of Ferritic Stainless Steels; Lula, R.A., Ed.; American Society for Testing and Materials: West Conshohocken, PA, USA, 1980; pp. 2-23.

68. Plumtree, A.; Gullberg, R. Embrittlement of a continuously cooled Fe-25 Cr alloy. Metall. Trans. 1976, 7, 1451-1458. [CrossRef]

69. Plumtree, A.; Gullberg, R. Influence of Interstitial and Some Substitutional Alloying Elements. In Toughness of Ferritic Stainless Steels; Lula, R., Ed.; ASTM Special Technical Publication 706: West Conshohocken, PA, USA, 1980; pp. 34-55.

(C) 2020 by the authors. Licensee MDPI, Basel, Switzerland. This article is an open access article distributed under the terms and conditions of the Creative Commons Attribution (CC BY) license (http://creativecommons.org/licenses/by/4.0/). 